\title{
Synthesis, molecular docking and molecular dynamic simulation studies of 2-chloro-5-[(4-chlorophenyl) sulfamoyl]- $N$-(alkyl/aryl)-4-nitrobenzamide derivatives as antidiabetic agents
}

\author{
Samridhi Thakral ${ }^{1}$, Rakesh Narang ${ }^{2}$, Manoj Kumar ${ }^{1}$ and Vikramjeet Singh ${ }^{1 *}$ (])
}

\begin{abstract}
A series of 2-chloro-5-[(4-chlorophenyl)sulfamoyl]- $N$-(alkyl/aryl)-4-nitrobenzamide derivatives (5a-5v) has been synthesized and confirmed by physicochemical( $R_{f}$, melting point) and spectral means (IR, $\left.{ }^{1} H N M R,{ }^{13} \mathrm{CNMR}\right)$. The results of in vitro antidiabetic study against a-glucosidase indicated that compound $\mathbf{5 0}$ bearing $2-\mathrm{CH}_{3}-5-\mathrm{NO}_{2}$ substituent on phenyl ring was found to be the most active compound against both enzymes. The electron donating $\left(\mathrm{CH}_{3}\right)$ group and electron withdrawing $\left(\mathrm{NO}_{2}\right)$ group on a phenyl ring highly favoured the inhibitory activity against these enzymes. The docking simulations study revealed that these synthesized compounds displayed hydrogen bonding, electrostatic and hydrophobic interactions with active site residues. The structure activity relationship studies of these compounds were also corroborated with the help of molecular modeling studies. Molecular dynamic simulations have been done for top most active compound for validating its a-glucosidase and a-amylase inhibitory potential, RMSD analysis of ligand protein complex suggested the stability of top most active compound $\mathbf{5 o}$ in binding site of target proteins. In silico ADMET results showed that synthesized compounds were found to have negligible toxicity, good solubility and absorption profile as the synthesized compounds fulfilled Lipinski's rule of 5 and Veber's rule.
\end{abstract}

Keywords: a-Glucosidase, a-Amylase, Molecular docking, Molecular dynamic simulations, ADMET

\section{Introduction}

Diabetes mellitus (DM) is a complex metabolic disorder resulting either due to relative or absolute deficiency of pancreatic insulin secretion or insensitivity to insulin action, ensuing in postprandial hyperglycemia and assorted diabetic complications [1,2]. According to World Health Organization reports, at present around 250 million peoples are living with diabetes and this

\footnotetext{
*Correspondence: vikramjeetsinghjudge@gmail.com

${ }^{1}$ Department of Pharmaceutical Sciences, Guru Jambheshwar University

of Science and Technology, Hisar 125001, India

Full list of author information is available at the end of the article
}

number is expected to be more than 366 million by 2030 [3] and these statistics are predicted to reach 592 million by 2035 of which $46 \%$ may still remain undiagnosed. The reduction of postprandial hyperglycemia by inhibiting carbohydrate hydrolyzing enzymes in gastrointestinal tract is one of the promising approaches for management of diabetes $[4,5]$. $\alpha$-Amylase is involved in hydrolyzing long chain of starch and $\alpha$-glucosidase release glucose into the small intestine by breaking down oligosaccharides and disaccharides [2,6]. $\alpha$-Glucosidase and $\alpha$-amylase inhibitors reduced postprandial blood glucose level by delaying the hydrolysis of carbohydrate by inhibiting the digestive enzymes [7]. Acarbose, Miglitol

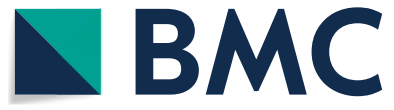

(c) The Author(s) 2020. This article is licensed under a Creative Commons Attribution 4.0 International License, which permits use, sharing, adaptation, distribution and reproduction in any medium or format, as long as you give appropriate credit to the original author(s) and the source, provide a link to the Creative Commons licence, and indicate if changes were made. The images or other third party material in this article are included in the article's Creative Commons licence, unless indicated otherwise in a credit line to the material. If material is not included in the article's Creative Commons licence and your intended use is not permitted by statutory regulation or exceeds the permitted use, you will need to obtain permission directly from the copyright holder. To view a copy of this licence, visit http://creativeco mmons.org/licenses/by/4.0/. The Creative Commons Public Domain Dedication waiver (http://creativecommons.org/publicdomain/ zero/1.0/) applies to the data made available in this article, unless otherwise stated in a credit line to the data. 
and Voglibose are currently available drugs used as $\alpha$-glucosidase and $\alpha$-amylase inhibitors, but due to their deleterious side effects such as abdominal distention, diarrhoea and bloating, flatulence [8-10] there is need to explore and synthesize new drug candidates for the management of type-II diabetes mellitus with no or low risk of side effects.

The sulphonamide moiety $\left(-\mathrm{SO}_{2} \mathrm{NH}_{2}\right)$ is an effective pharmacophore revealing the clinical and medicinal importance of sulphonamide drugs in the field of drug discovery [11]. The lead molecules bearing sulphonamide structure exhibited diverse biological properties viz. antibacterial $[12,13]$, diuretics, carbonic anhydrase (CA) inhibitors [14], antithyroid, antidiabetic [11, 15, 16], anticancer [17], antitubercular [18], selective Cox II inhibitors [19], anti-inflammatory [20], aldose reductase inhibitor [21], anti-oxidant [22], and anticancer [20] etc. Benzamides are the carbonic acid amide of benzoic acid and have also been described for exhibiting various biological activities i.e. antimicrobial [23, 24], antiinflammatory [25], anticancer [26, 27], antidiabetic [28], antidepressant, antitubercular [29], anticonvulsant [30] and analgesic [31] etc. 2,4-Dichlorobenzoic acid derivatives have also been reported for their antidiabetic potential exhibiting $\alpha$-glucosidase and $\alpha$-amylase inhibitory activity, as described in our previous studies [32, 33]. Singh et al., reported the benzamides as glucokinase activators possessing hypoglycaemic activity [34]. Thiazole2 -yland $N$-pyridin-2-yl benzamides from benzoic acids showed glucokinase activation and possessed good antidiabetic potential in animal rat model $[35,36]$. A series of sulfamoyl benzamide derivatives have also been reported by Grewal et al., having glucokinase activation potential for the treatment of type 2 diabetes [37]. In view of the vital importance of benzamides in management of type 2 diabetes, we have synthesized a series of 2-chloro5-[(4-chlorophenyl)sulfamoyl]- $N$-(alkyl/aryl)-4-nitrobenzamides and evaluated its antidiabetic potential in the current report.

\section{Results and discussion Chemistry}

The 2-chloro-5-(chlorosulfonyl)-4-nitrobenzoic acid (2) was prepared from 2-chloro-4-nitro benzoic acid according to our previously reported procedure [32]. The reaction of commercially available para chloro substituted aniline with compound 2 in DMF yielded 2-chloro-5-[(4chlorophenyl)sulfamoyl]-4-nitrobenzoic acid in appropriate amount. The treatment of compound 3 with excess of thionyl chloride in presence of DMF as a catalyst afforded intermediate 4 , which was further refluxed with aromatic/aliphatic/heterocyclic amines in DMF to provide the target compounds $\mathbf{5 a - 5 v}$ (Table 1, Scheme 1).
The structure of 2-chloro-5-[(4-chlorophenyl) sulfamoyl]- $N$-(alkyl/aryl)-4-nitrobenzamide compounds was elucidated by IR, ${ }^{1} \mathrm{H}$ NMR and ${ }^{13} \mathrm{C}$ NMR spectral analysis. The stretching frequency due to $\mathrm{NH}$ and carbonyl of amide bond were obtained at 3294-3524 cm and 1614-1692 $\mathrm{cm}^{-1}$ respectively. The bands around $1302-1398 \mathrm{~cm}^{-1}$ and $1127-1183 \mathrm{~cm}^{-1}$ were assigned to asymmetric and symmetric stretching of $\mathrm{SO}_{2}$ of sulfonamide group respectively. The IR spectrum of synthesized compounds exhibits a band around $1506-1587 \mathrm{~cm}^{-1}$ to $1302-1378 \mathrm{~cm}^{-1}$ assignable to asymmetric and symmetric stretching of $\mathrm{NO}_{2}$. In the ${ }^{1} \mathrm{H}$ NMR spectra of compound, singlet for $\mathrm{NH}$ protons of $\mathrm{SO}_{2} \mathrm{NH}$ and $\mathrm{CONH}$ appeared at $\delta 3.37-4.08 \mathrm{ppm}$ and $\delta 10.19-10.81 \mathrm{ppm}$, respectively. The two aromatic protons of 2-chloro4-nitro benzoic acid appeared around at $\delta 8.50 \mathrm{ppm}$ and $\delta 7.50 \mathrm{ppm}$. The aromatic protons showed the chemical shift values in region of $\delta 6.58-8.58 \mathrm{ppm}$ based on their chemical structure. In ${ }^{13} \mathrm{C}$ NMR, signals for various carbons appeared in the region of $\delta 17.72$ to $168.51 \mathrm{ppm}$.

\section{In vitro antidiabetic evaluation a-Glucosidase inhibitory activity}

All the synthesized compounds were tested for their in vitro $\alpha$-glucosidase inhibitory activity and revealed their varying degree of inhibitory potential with $\mathrm{IC}_{50}$ values of $10.75 \pm 0.52$ to $130.90 \pm 2.42 \mu \mathrm{M}$ (Table 2) as compared to reference acarbose $\left(\mathrm{IC}_{50}=39.48 \pm 0.80 \mu \mathrm{M}\right)$. The compound 5o $\left(\mathrm{R}=2-\mathrm{CH}_{3}-5-\mathrm{NO}_{2}\right)$ was found to be most active among this series of synthesized compounds. Most of the compounds exhibited good inhibitory potential with significant $\mathrm{IC}_{50}$ as compared to positive reference.

\section{a-Amylase inhibitory activity}

All the compounds were also evaluated for $\alpha$-amylase inhibitory activity and the inhibition potential with $\mathrm{IC}_{50}$ values were found in range of $0.90 \pm 0.31 \mu \mathrm{M}$ to $55.14 \pm 0.71 \mu \mathrm{M}$ (Table 2). The compound 5o showed excellent inhibitory potential against $\alpha$-amylase with $\mathrm{IC}_{50}$ value of $0.90 \pm 0.31 \mu \mathrm{M}$. Compounds $\mathbf{5 b}, \mathbf{5 m}, \mathbf{5 p}$ showed most significant inhibitory potential against $\alpha$-amylase with $\mathrm{IC}_{50}$ values of $5.30 \pm 1.23,1.52 \pm 0.84$ and $2.10 \pm 0.52 \mu \mathrm{M}$, respectively, when compared to acarbose, used as reference compound $\left(\mathrm{IC}_{50}=5.60 \pm 0.30 \mu \mathrm{M}\right)$.

\section{Structure activity relationship}

The compound 5o $\left(\mathrm{R}=2-\mathrm{CH}_{3}-5-\mathrm{NO}_{2}\right)$ was the most active compound $\left(\mathrm{IC}_{50}=10.75 \pm 0.52 \mu \mathrm{M}\right.$; $0.90 \pm 0.31 \mu \mathrm{M})$ which may be due to the presence of electron withdrawing and electron donating group which generate an uniform electron flow, leading the compound to be more active and potent inhibitor against both enzymes. This fact is supported by the similar results 
Table 1 List of synthesized 2-chloro-5-[(4-chlorophenyl)sulfamoyl]-N-(alkyl/aryl)-4-nitrobenzamide compounds

\begin{tabular}{|l|l|l|}
\hline Comp. & Comp. \\
\hline $5 \mathrm{~m}$
\end{tabular}

of Adegboye et al. [38]. In compounds $5 \mathrm{~m}\left(\mathrm{R}=2-\mathrm{CH}_{3}\right.$ $\left.3-\mathrm{NO}_{2}\right)$ and $5 \mathbf{p}\left(\mathrm{R}=2-\mathrm{CH}_{3}-4-\mathrm{NO}_{2}\right)$ difference in inhibitory potential was mainly affected by position of $\mathrm{NO}_{2}$ substituent.

However the inhibitory activity increased when the phenyl ring was substituted with $\mathrm{CH}_{3}$ at meta position, as observed in compound $\mathbf{5 b}\left(\mathrm{IC}_{50}=24.78 \pm 2.69 \mu \mathrm{M}\right.$; $5.30 \pm 1.23 \mu \mathrm{M})$ in comparison to compounds $\mathbf{5 a}$ and 5c having $\mathrm{CH}_{3}$ substitution at para and ortho positions. Further a decrease in inhibitory activity was observed for compounds $5 \mathbf{d}\left(\mathrm{IC}_{50}=38.57 \pm 0.01 \mu \mathrm{M} ; 38.00 \pm 0.51 \mu \mathrm{M}\right)$ and $5 \mathbf{e}\left(\mathrm{IC}_{50}=41.75 \pm 1.08 \mu \mathrm{M} ; 50.30 \pm 0.21 \mu \mathrm{M}\right)$ bearing $\mathrm{OCH}_{3}$ substituted phenyl ring instead of compounds having $\mathrm{CH}_{3}$ substituted phenyl ring. The compounds $\mathbf{5 f}-\mathbf{5 k}, \mathbf{5 q}$ and $\mathbf{5 r}$ bearing electron withdrawing groups were found to have considerable inhibitory potential.
The results illustrated that compounds $5 \mathrm{~g}(\mathrm{R}=3-\mathrm{Br}), \mathbf{5 i}$ $(\mathrm{R}=3-\mathrm{Cl}), 5 \mathbf{r}\left(\mathrm{R}=3-\mathrm{NO}_{2}\right)$, substitution at meta position of phenyl ring was found to be most favored for the $\alpha$-glucosidase inhibitory activity while compounds $\mathbf{5 f}$ and $\mathbf{5 q}$ bearing electron withdrawing groups at para position were found to be most favorable for $\alpha$-amylase inhibitory activity. This fact is supported by Taha et al. [39]. The compounds $5 \mathbf{u}\left(\mathrm{IC}_{50}=89.04 \pm 1.76 \mu \mathrm{M}, 38.20 \pm 0.34 \mu \mathrm{M}\right)$ and $5 \mathbf{v}\left(\mathrm{IC}_{50}=52.37 \pm 1.92 \mu \mathrm{M}, 40.40 \pm 0.87 \mu \mathrm{M}\right)$ substituted with heterocyclic amine displayed reduced inhibitory activities compared to aryl amines. This fact is supported by similar results of Kumar et al. [40] and Charaya et al. [35]. Substituting the compounds with $n$-propyl amine and butyl amine resulted in diminished activity as in compounds $5 \mathbf{s}\left(\mathrm{IC}_{50}=106.23 \pm 0.61 \mu \mathrm{M}\right.$, $48.05 \pm 0.23 \mu \mathrm{M})$ and 5t $\left(\mathrm{IC}_{50}=130.90 \pm 2.42 \mu \mathrm{M}\right.$, 


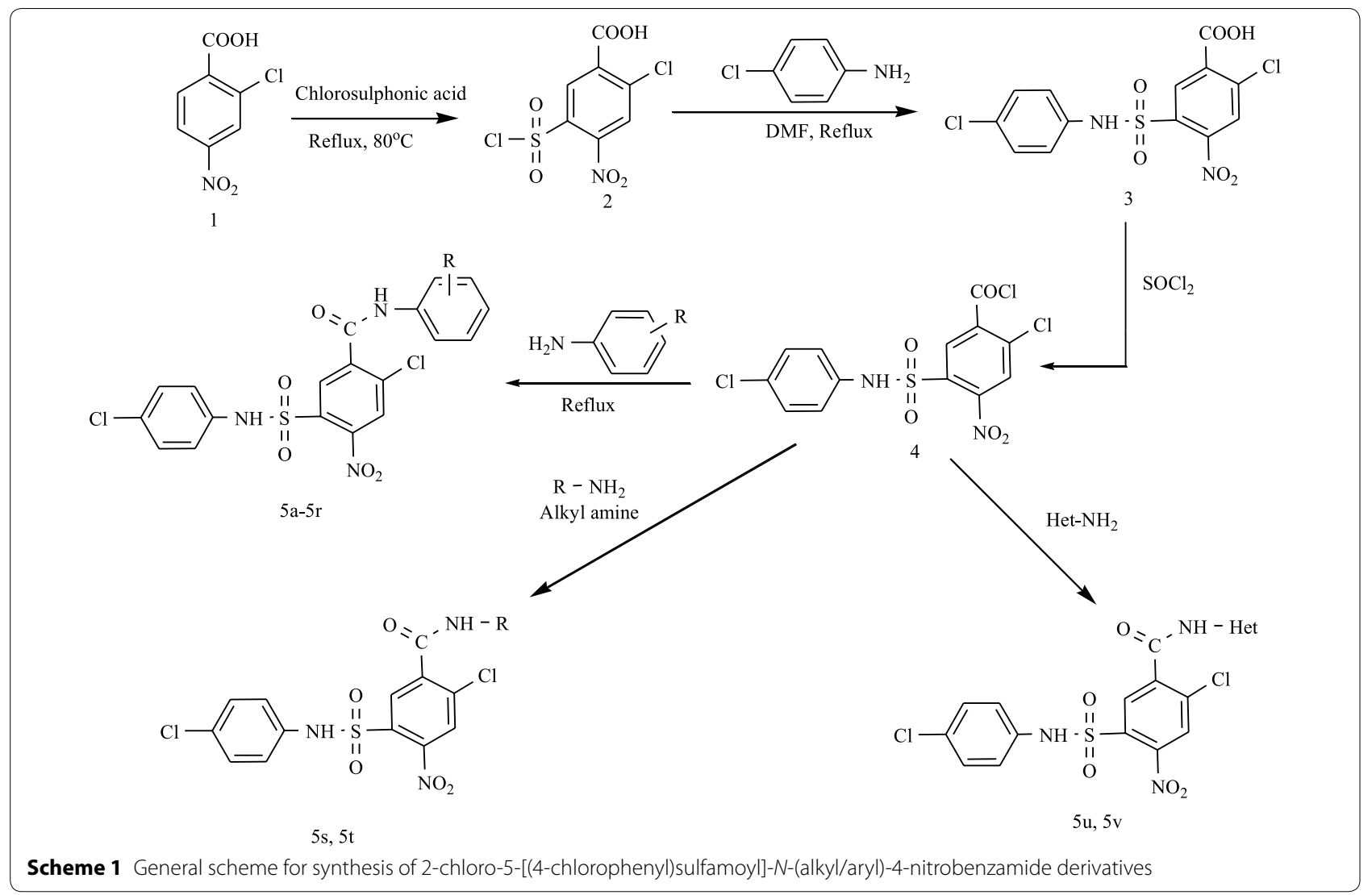

$55.14 \pm 0.71 \mu \mathrm{M})$. This fact is supported by the similar study on benzamide derivatives by Charaya et al. [35].

\section{Molecular docking}

In silico molecular docking study was performed to investigate binding interactions and to explore binding modes of synthesized compounds with their respective targets. The binding affinities of all the synthesized compounds are reported in Table 2 .

\section{a-Glucosidase enzyme}

The docking results revealed that all the synthesized compounds displayed binding energy ranging from -9.7 to $-8.0 \mathrm{kcal} / \mathrm{mol}$ and depicted various types of significant binding interactions like hydrogen bonding, electrostatic and hydrophobic interactions with the amino acid residues of active site of enzyme. The binding mode of most active compound $\mathbf{5 0}$ and modeled protein is presented in Fig. 1. The oxygen of $2-\mathrm{Cl}-4-\mathrm{NO}_{2}$ established hydrogen bonding interaction with Glu:276 amino acid residue at a distance of $3.35 \AA$ whereas Phe:298 amino acid was found to engage in hydrogen bond interactions with both protonated nitrogen of $\mathrm{NO}_{2}$ of same with bond lengths of $2.49 \AA$. The nitrogen of $2-\mathrm{CH}_{3}-5-\mathrm{NO}_{2}$ substituted compound displayed charge-charge interaction with Asp:349 amino acid residue (3.78 $\AA$ ) while the nitrogen of 2-Cl-4- $\mathrm{NO}_{2}$ presented charge-charge interaction with Glu:276 amino acid residue (3.80 ̊). The 2-Cl-4- $\mathrm{NO}_{2}$ substituted phenyl ring created pi-anion interaction with residue Glu:276 of modeled protein at a distance of $3.37 \AA$. It was noticed that Phe: 157 residue (5.51 $\AA$ ) formed pi-pi T shaped interaction with $2-\mathrm{CH}_{3}$ 5- $\mathrm{NO}_{2}$ substituted phenyl ring and para chloro substituted phenyl ring displayed two pi-pi $\mathrm{T}$ shaped and one pi-pi stacked interaction with His:348, Tyr:344 and Phe:298 amino acid residues. In addition 2-Cl-4- $\mathrm{NO}_{2}$ substituted phenyl ring created pi-pi stacked and pi-pi $\mathrm{T}$ shaped interaction with His:279 amino acid residues with bond length of $5.77 \AA$. Pi-alkyl interactions were established by chlorine of 2-Cl-4- $\mathrm{NO}_{2}$ substituted phenyl ring with His:279 residues at a distance of $4.14 \AA$. The chlorine of para chlorosubstituted phenyl ring was found to engage in forming pi-alkyl interactions with Tyr:344, His:348, Phe:298, Trp:57 amino acid residues of modeled protein. The involvement of $2-\mathrm{CH}_{3}-5-\mathrm{NO}_{2}$ substituted phenyl ring in forming more hydrophobic interactions i.e. pi-pi interactions may be contributing to better activity of compound $\mathbf{5 0}$ as compared to compounds $5 \mathbf{n}\left(\mathrm{R}=2-\mathrm{CH}_{3}-3-\mathrm{NO}_{2}\right)$ and $\mathbf{5 p}\left(2-\mathrm{CH}_{3}-\right.$ 4- $\left.\mathrm{NO}_{2}\right)$. Comparison of compound $5 \mathbf{c}\left(\mathrm{R}=2-\mathrm{CH}_{3}\right)$ with 
Table 2 a-Glucosidase and a-amylase inhibitory activity $\left(\mathrm{IC}_{50}\right)$ of synthesized derivatives $(5 \mathrm{a}-5 \mathrm{v})$ and their docking affinity with a-glucosidase (modeled protein) and a-amylase (PDB-1 qho)

\begin{tabular}{|c|c|c|c|c|}
\hline Comp. & $\mathrm{IC}_{50}$ a-glucosidase $(\mu \mathrm{M})$ & $\begin{array}{l}\text { Binding score (a-glucosidase: } \\
\text { modeled protein) }\end{array}$ & $\mathrm{IC}_{50}$ a-amylase $(\mu \mathrm{M})$ & $\begin{array}{l}\text { Binding score } \\
\text { (a-amylase: } \\
\text { 1qho) }\end{array}$ \\
\hline $5 a$ & $31.39 \pm 1.66$ & -9.4 & $7.40 \pm 0.15$ & -8.9 \\
\hline $5 b$ & $24.78 \pm 2.69$ & -9.7 & $5.30 \pm 1.23$ & -9.0 \\
\hline $5 c$ & $26.77 \pm 1.13$ & -9.3 & $8.00 \pm 0.71$ & -9.8 \\
\hline $5 d$ & $38.57 \pm 0.01$ & -9.2 & $38.00 \pm 0.51$ & -9.1 \\
\hline $5 e$ & $41.75 \pm 1.08$ & -9.3 & $50.30 \pm 0.21$ & -8.7 \\
\hline $5 f$ & $50.24 \pm 0.89$ & -9.4 & $16.00 \pm 0.33$ & -9.7 \\
\hline $5 g$ & $35.92 \pm 0.60$ & -9.6 & $16.70 \pm 0.41$ & -9.8 \\
\hline $5 \mathrm{~h}$ & $40.64 \pm 1.49$ & -9.6 & $19.30 \pm 0.63$ & -9.7 \\
\hline $5 i$ & $14.02 \pm 0.93$ & -9.5 & $27.12 \pm 0.51$ & -8.5 \\
\hline $5 j$ & $15.75 \pm 0.90$ & -9.6 & $20.90 \pm 1.24$ & -9.5 \\
\hline $5 k$ & $36.93 \pm 1.30$ & -9.7 & $12.50 \pm 0.91$ & -8.8 \\
\hline 51 & $29.01 \pm 0.86$ & -9.3 & $6.30 \pm 0.42$ & -9.3 \\
\hline $5 m$ & $24.47 \pm 1.23$ & -9.4 & $1.52 \pm 0.84$ & -9.7 \\
\hline $5 n$ & $29.54 \pm 1.53$ & -9.4 & $35.30 \pm 0.45$ & -9.6 \\
\hline 50 & $10.75 \pm 0.52$ & -9.3 & $00.90 \pm 0.31$ & -9.2 \\
\hline $5 p$ & $19.51 \pm 0.43$ & -9.4 & $02.10 \pm 0.52$ & -9.1 \\
\hline $5 q$ & $43.88 \pm 1.18$ & -9.4 & $11.20 \pm 0.67$ & -9.0 \\
\hline $5 r$ & $34.36 \pm 0.62$ & -9.7 & $15.30 \pm 1.24$ & -9.4 \\
\hline $5 s$ & $106.23 \pm 0.61$ & -8.2 & $48.05 \pm 0.23$ & -7.9 \\
\hline $5 t$ & $130.90 \pm 2.42$ & -8.6 & $55.14 \pm 0.71$ & -8.3 \\
\hline $5 u$ & $89.04 \pm 1.76$ & -8.9 & $38.20 \pm 0.34$ & -8.6 \\
\hline $5 v$ & $52.37 \pm 1.92$ & -9.0 & $40.40 \pm 0.87$ & -8.9 \\
\hline Acarbose & $39.48 \pm 0.88$ & -8.0 & $5.60 \pm 0.30$ & -8.4 \\
\hline
\end{tabular}

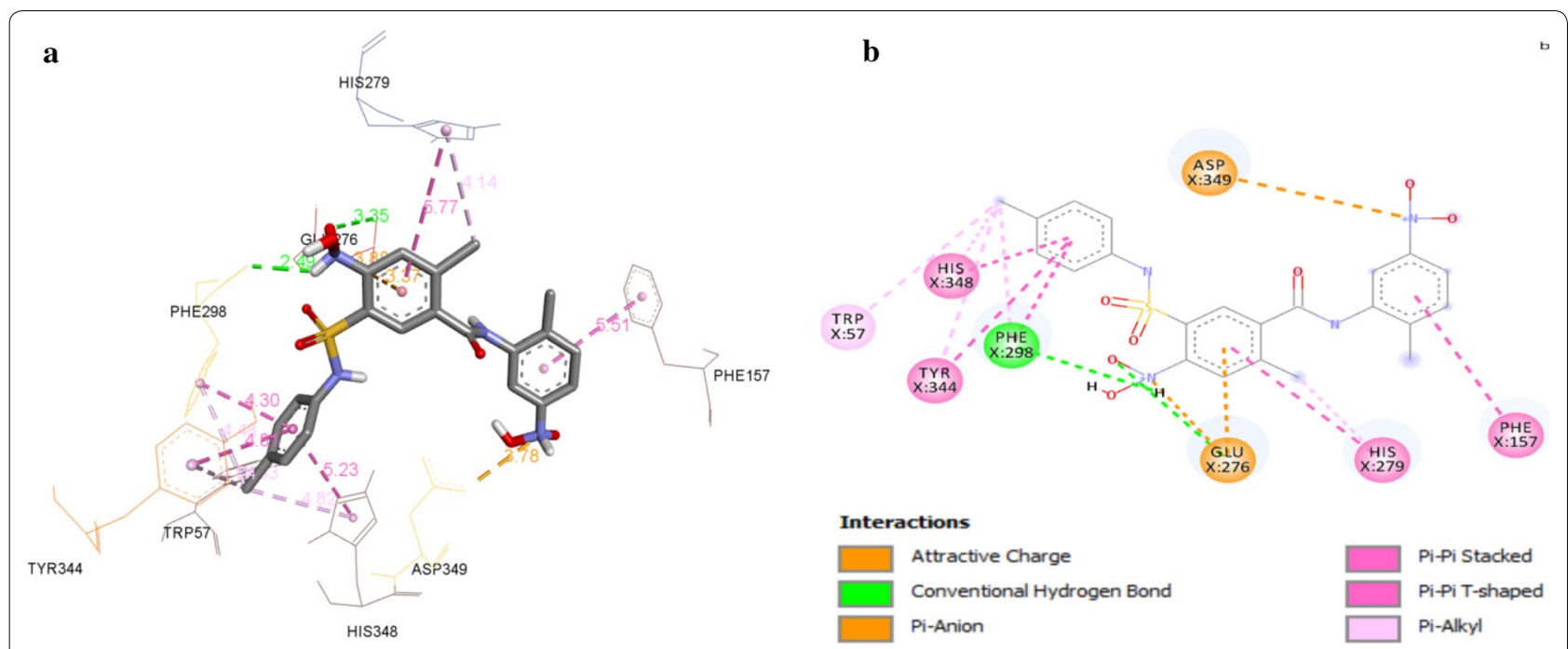

Fig. 1 a 3D Binding confirmation of compound 50 with active site residues of a-glucosidase. $\mathbf{b}$ 2D binding confirmation of compound 50 with amino acid residue of nearby active site 
5n $\quad\left(\mathrm{R}=2-\mathrm{CH}_{3}-3-\mathrm{NO}_{2}\right)$, 5o $\left(\mathrm{R}=2-\mathrm{CH}_{3}-5-\mathrm{NO}_{2}\right), \quad$ 5p $\left(\mathrm{R}=2-\mathrm{CH}_{3}-4-\mathrm{NO}_{2}\right), 5 \mathbf{n}, 5 \mathbf{5}, 5 \mathbf{p}$ displayed more hydrophobic interactions with Phe:177, Arg:312, Val:108, His:279, Phe:157, His:348, Tyr:344, Phe:298 amino acid residues of modeled protein which may have resulted in their higher inhibitory potential. The binding interaction between compounds $5 \mathbf{c}\left(\mathrm{R}=2-\mathrm{CH}_{3}\right)$ and residues of modeled protein was nearly same as $\mathbf{5 a}\left(\mathrm{R}=4-\mathrm{CH}_{3}\right)$ and $5 \mathbf{b}\left(\mathrm{R}=3-\mathrm{CH}_{3}\right)$. The difference was that ortho methyl substituted phenyl ring maintained pi-pi stacked, pialkyl and pi-pi T interactions (hydrophobic interactions) with Try:344, His:348, Phe:298, Phe:177, Phe:158, Tyr:344 amino acid residue that made $\mathbf{5 c}$ more active than $\mathbf{5 a}$ and $5 \mathbf{b}$.

The compound 5e $\left(\mathrm{R}=2-\mathrm{OCH}_{3}\right)$ formed less number of hydrogen bonding, electrostatic and hydrophobic interactions as compared to compound $\mathbf{5 d}\left(\mathrm{R}=4-\mathrm{OCH}_{3}\right)$, resulting in decreased inhibitory potential of compound 5e. The binding of compound $5 \mathbf{i}(\mathrm{R}=3-\mathrm{Cl})$ facilitated one more pi-alkyl interaction with other hydrogen bonding, hydrophobic and electrostatic interactions same as that of compound $5 \mathbf{j}(\mathrm{R}=2-\mathrm{Cl})$, which may be contributing to better potential of compound $5 \mathbf{i}$. Considering the moderately active compound $\mathbf{5 r}\left(\mathrm{R}=3-\mathrm{NO}_{2}\right)$, additional hydrophobic interaction such as pi-pi interactions with amino acid residues were observed as compared to compounds $5 \mathbf{k}\left(\mathrm{R}=2-\mathrm{NO}_{2}\right)$ and $\mathbf{5 q}\left(\mathrm{R}=4-\mathrm{NO}_{2}\right)$. In comparison to compounds bearing aromatic anilines, a decrease in inhibitory potential was observed in compounds $\mathbf{5 s}$ ( $\mathrm{R}=n$-propyl), and $5 \mathrm{t}$ ( $\mathrm{R}=n$-butyl), due to less $\mathrm{pi}-\mathrm{pi}$ interactions between the inhibitory compounds and amino acid residues. The binding interactions of compound $5 \mathbf{u} \quad\left(\mathrm{R}=\mathrm{C}_{4} \mathrm{H}_{3} \mathrm{O}-\mathrm{CH}_{2}\right.$ (2-furfuryl)) with residues of modeled protein were nearly same as that of $\mathbf{5 v}$ $\left(\mathrm{R}=\mathrm{C}_{5} \mathrm{H}_{5} \mathrm{~N}\right.$-(pyridine-2-yl)) but the difference was that 2-furfuryl ring exhibited pi-pi $\mathrm{T}$ shaped interaction with Trp:177 residue and four hydrogen bond interaction with Asp:329, Arg:376, His:90, Trp:93 residues of $\alpha$-glucosidase with other interactions while compound $\mathbf{5 v}$ formed three hydrogen bond interactions, which made $5 \mathbf{u}$ more active than $\mathbf{5 v}$ against $\alpha$-glucosidase enzyme.

\section{a-Amylase enzyme}

The docking results revealed that all the synthesized compounds displayed binding energy ranging from -9.8 to $-7.9 \mathrm{kcal} / \mathrm{mol}$. The binding mode of most active compound 50 and 1qho is presented in Fig. 2. The oxygen of $2-\mathrm{CH}_{3}-5-\mathrm{NO}_{2}$ established hydrogen bonding interaction with His:90 amino acid residue at a distance of $3.01 \AA$ whereas His:232 amino acid was found to engage in hydrogen bond interactions with both oxygen of $\mathrm{NO}_{2}$ of 2-Cl-4- $\mathrm{NO}_{2}$ substituted phenyl ring with bond lengths of $2.04 \AA$ and $1.86 \AA$. The nitrogen of $2-\mathrm{CH}_{3}-5-\mathrm{NO}_{2}$ displayed charge-charge interaction with Asp:372 amino acid residue $(4.82 \AA)$ while the protonated nitrogen of 2- $\mathrm{CH}_{3}-5-\mathrm{NO}_{2}$ presented salt bridge charge-charge interaction with Asp:190 amino acid residue (3.14 A). The charge-charge interaction was also found between the nitrogen of 2-Cl-4- $\mathrm{NO}_{2}$ substituted phenyl ring and Glu:256 amino acid residue with bond length of $5.09 \AA$. The $2-\mathrm{CH}_{3}-5-\mathrm{NO}_{2}$ substituted phenyl ring created pianion interaction with residue Asp:372 of $\alpha$-amylase

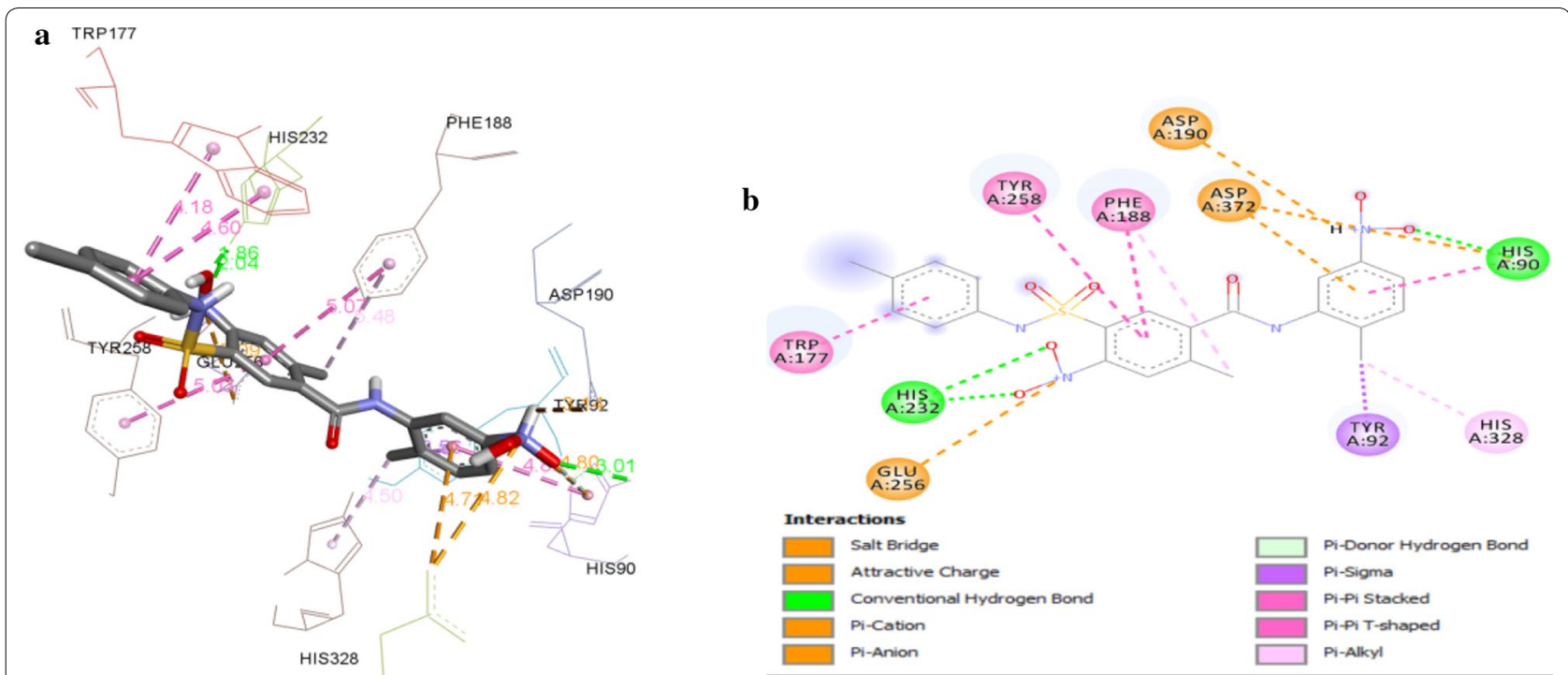

Fig. 2 a 3D Binding confirmation of compound 50 with active site residues of a-amylase. $\mathbf{b} 2 \mathrm{D}$ binding confirmation of compound 50 with amino acid residue of nearby active site 
while nitrogen of 2- $\mathrm{CH}_{3}-5-\mathrm{NO}_{2}$ substituted phenyl ring formed pi-cation interaction with His:90 residue. It was shown that His:90 residue (4.88 $\AA$ ) formed pi-pi T shaped interaction with $2-\mathrm{CH}_{3}-5-\mathrm{NO}_{2}$ substituted phenyl ring and para chloro substituted phenyl ring displayed pi-pi stacked interaction with Trp:177 residue $(4.60 \AA)$. In addition 2-Cl-4- $\mathrm{NO}_{2}$ substituted phenyl ring created pi-pi stacked and pi-pi $\mathrm{T}$ shaped interaction with Tyr:258, Phe:188 amino acid residues with bond lengths of $5.3 \AA$ and $5.07 \AA$, respectively. The pi-alkyl interactions were established by chlorine of $2-\mathrm{Cl}-4-\mathrm{NO}_{2}$ substituted phenyl ring and methyl of $2-\mathrm{CH}_{3}-5-\mathrm{NO}_{2}$ substituted phenyl ring with Phe:188 and His:328 residues at a distance of $5.48 \AA$ and $4.50 \AA$, respectively. The $\mathrm{CH}_{3}$ of $2-\mathrm{CH}_{3}-5-\mathrm{NO}_{2}$ substituted phenyl ring was found to engage in forming pi-sigma interaction with Tyr:92 residue $(3.56 \AA)$ while oxygen of $\mathrm{NO}_{2}$ created pi-donor hydrogen bond with His:90 residue at a distance of 4.01 $\AA$.

The involvement of $2-\mathrm{CH}_{3}-5-\mathrm{NO}_{2}$ substituted phenyl ring in forming more hydrophobic interactions may be contributing to better activity of compound $\mathbf{5 o}$ as compared to compounds $5 \mathbf{n}\left(\mathrm{R}=2-\mathrm{CH}_{3}-3-\mathrm{NO}_{2}\right)$ and 5p $\left(2-\mathrm{CH}_{3}-4-\mathrm{NO}_{2}\right)$.The comparison of compound $\mathbf{5 c}$ $\left(\mathrm{R}=\mathrm{CH}_{3}\right)$ with 5n $\left(\mathrm{R}=2-\mathrm{CH}_{3}-3-\mathrm{NO}_{2}\right)$, 5o $\left(\mathrm{R}=2-\mathrm{CH}_{3}-\right.$ $\left.5-\mathrm{NO}_{2}\right)$ and $5 \mathbf{p}\left(\mathrm{R}=2-\mathrm{CH}_{3}-4-\mathrm{NO}_{2}\right), 5 \mathbf{n}, 5 \mathbf{0}, 5 \mathbf{p}$ displayed more electrostatic and hydrophobic interactions with Asp:372, Asp:190, Glu:256, His:90, Trp:177, Tyr:258, Phe:188, His:328 and Tyr:92 residues of $\alpha$-amylase enzyme, which may have resulted in increase in inhibitory potential. The binding interactions between compound $5 \mathbf{b}\left(\mathrm{R}=3-\mathrm{CH}_{3}\right)$ and residues of $\alpha$-amylase were nearly same as $\mathbf{5 a}\left(\mathrm{R}=4-\mathrm{CH}_{3}\right)$ and $\mathbf{5 c}\left(\mathrm{R}=2-\mathrm{CH}_{3}\right)$. The difference was that meta methyl substituted phenyl ring and methyl group maintained pi-pi stacked, pi-alkyl and pi-sigma interactions (hydrophobic interactions) with Trp:177 amino acid residue which made 5b more active than $\mathbf{5 a}$ and $\mathbf{5 c}$. The compound $\mathbf{5 e}\left(\mathrm{R}=2-\mathrm{OCH}_{3}\right)$ formed less number of hydrogen bonding, electrostatic and hydrophobic interactions as compared to compound 5d $\left(\mathrm{R}=4-\mathrm{OCH}_{3}\right)$, resulting in decrease in inhibitory potential of compound $5 \mathbf{e}$. The binding of compound $\mathbf{5 f}$ $(\mathrm{R}=4-\mathrm{Br})$ facilitated two pi-pi $\mathrm{T}$ shaped and one pi-pi stacked interaction of para bromo substituted phenyl ring with Tyr:258, Phe:188, Trp:177 amino acid residues and two pi-pi stacked interactions of para chloro substituted phenyl ring with phe:188, Tyr:92 amino acid residues with other interactions, which made compound 5f more active than compounds $5 \mathrm{~g}(\mathrm{R}=3-\mathrm{Br})$ and $\mathbf{5 h}$ $(\mathrm{R}=2-\mathrm{Br})$. Considering the moderate active compound 5q $\left(\mathrm{R}=4-\mathrm{NO}_{2}\right)$, additional hydrophobic interaction such as pi-pi T shaped, pi-pi stacked interactions with Tyr:258 and Trp:177 residues were observed as compared to compounds $5 \mathbf{k}\left(\mathrm{R}=2-\mathrm{NO}_{2}\right)$ and $\mathbf{5 r}\left(\mathrm{R}=3-\mathrm{NO}_{2}\right)$. In comparison to compounds bearing aromatic anilines, a decrease in inhibitory potential was observed in compounds $5 \mathbf{s}(\mathrm{R}=n$-propyl), and $5 \mathrm{t}(\mathrm{R}=n$-butyl), due to less pi-pi interactions between the inhibitory compounds and amino acid residues. The binding interaction of compound $\mathbf{5 u}\left(\mathrm{R}=\mathrm{C}_{4} \mathrm{H}_{3} \mathrm{O}-\mathrm{CH}_{2}\right.$ (2-furfuryl)) with residues of $\alpha$-amylase was nearly same as $5 \mathbf{v}\left(\mathrm{R}=\mathrm{C}_{5} \mathrm{H}_{5} \mathrm{~N}\right.$ (pyridine-2-yl))but the difference was that 2-furfuryl ring exhibited pi-pi T shaped interaction with Trp:177 residue and four hydrogen bond interactions with Asp:329, Arg:376, His:90, Trp:93 residues of $\alpha$-amylase with other interactions while compound $\mathbf{5 v}$ formed three hydrogen bond interactions, which made $\mathbf{5 u}$ more active than $\mathbf{5 v}$ against $\alpha$-amylase.

\section{Molecular dynamics study}

A stable protein backbone atoms RMSD vs time is an indication of the near-equilibrium system. As shown in Fig. 3a and b, the protein backbone in both systems attains a constant phase after an initial surge. Whereas, due to the extensive involvement of water molecules $(-500 \mathrm{~kJ} / \mathrm{mol})$ the ligand-bound protein backbone has higher RMSD fluctuations compared to the naked protein as represented in Fig. 3a. Figure 4 represent that electrostatic interactions are dominated between the ligand $\mathbf{5 o}$ and protein.

The results obtained from the MD simulations demonstrated that water molecules are predominately involved in ligand-protein interactions (Fig. 5). As shown in the figure, the fall in electrostatic energy that corresponds to the ligand-protein interactions is compensated by the water molecules.

\section{In silico ADMET properties prediction}

Lipinski's rule of five, topological polar surface area, aqueous solubility and number of rotatable bonds, these calculated parameters are presented in Additional file 1: Table S1. The human intestinal absorption values were found in range of 93.10 to $95.93 \%$ which established the moderate to good absorption capacity of synthesized compounds and supported their interaction with target cell.

The in vitro Caco-2 cell permeable property in the range of $0.36-0.55 \mathrm{~nm} / \mathrm{s}$, in vitro MDCK cell permeability in range of $0.01-0.97 \mathrm{~nm} / \mathrm{s}$ designated low permeability of target compounds with the concerned cell line. The synthesized compounds displayed values in range of $95.75-100 \%$ confirmed their strong binding capacity with proteins. The in vivo blood brain barrier penetration ranges from 0.01 to 0.32 supported their low to moderate distribution in vivo with medium to good penetration capacity (Additional file 1: Table S2). Bioactivity and 

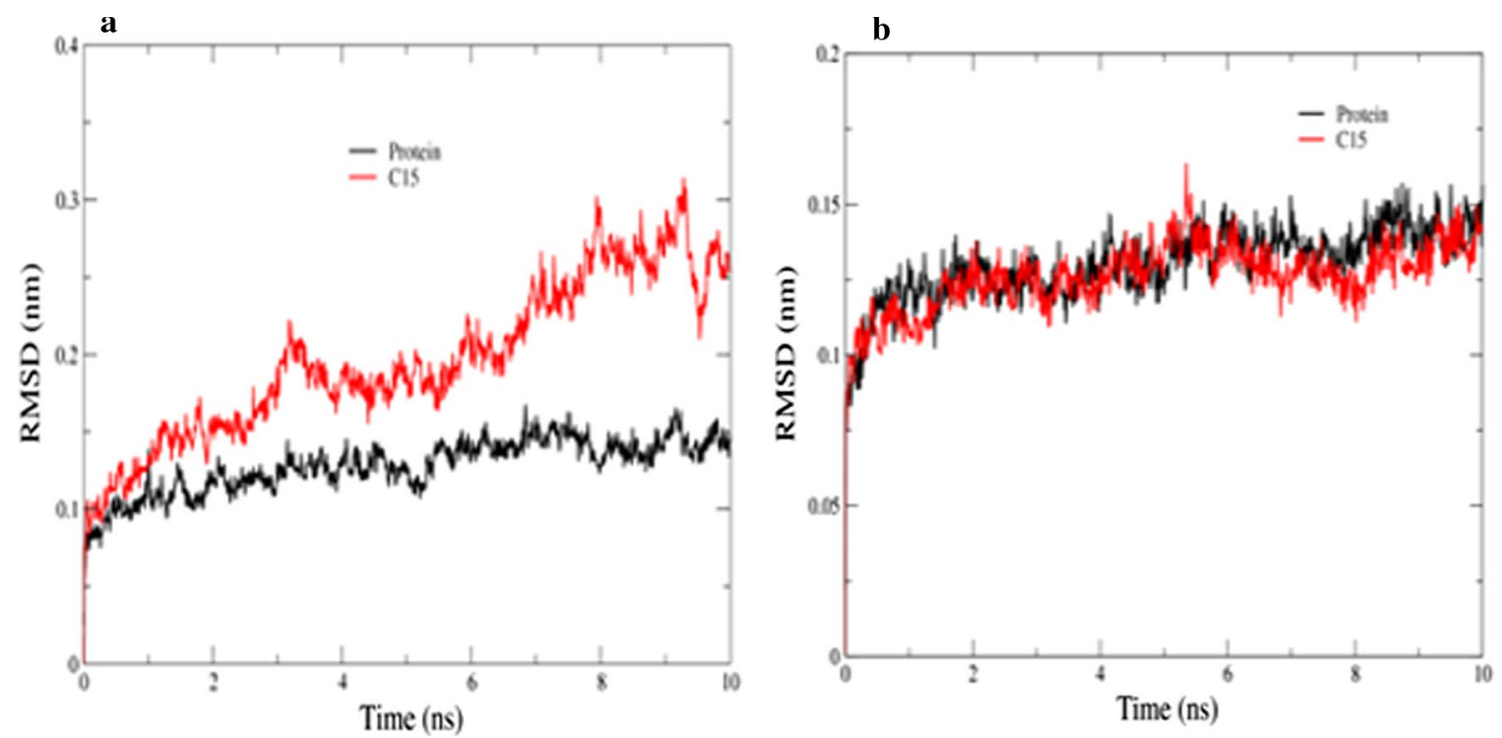

Fig. 3 Plot of protein backbone RMSD against time where red color line represent 50 bound modeled protein and black line represent naked protein. a For 3 aj7 modeled protein with 50 . b For 1 gho with 50
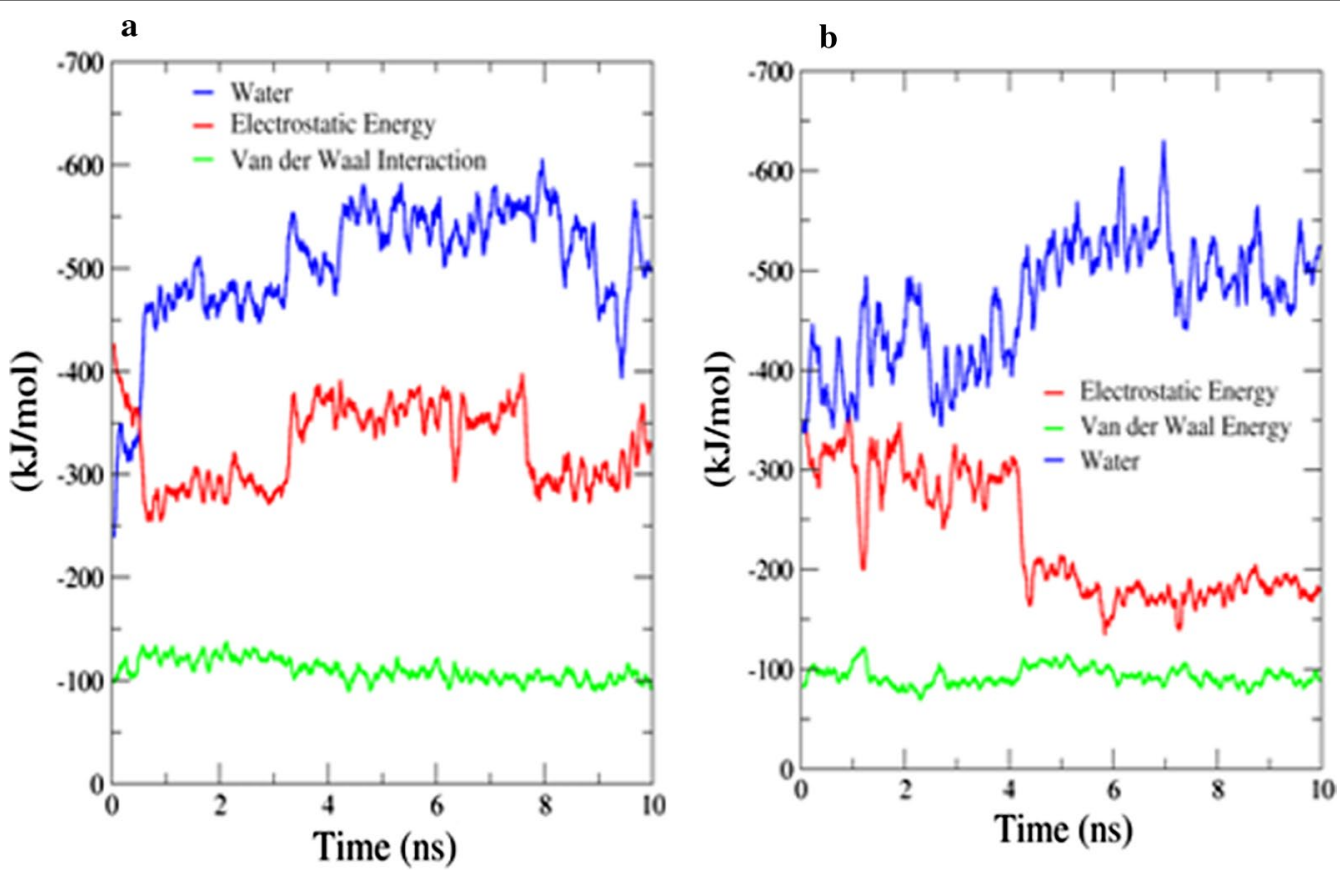

Fig. 4 Plot of binding energy (electrostatic and Van der Waal) vs time: a For 3aj7 modeled protein with 50. b For 1qho with 50

toxicity risk values of synthesized compounds are illustrated in Additional file 1: Table S3.

\section{Conclusion}

A series of 2-chloro-5-[(4-chlorophenyl)sulfamoyl]- $N$ (alkyl/aryl)-4-nitrobenzamide derivatives $(\mathbf{5 a}-\mathbf{5 v})$ has been synthesized and all the compounds were found to possess potent to moderate inhibitory potential against $\alpha$-glucosidase and $\alpha$-amylase. Compound 50 (2-chloro-5-[(4-chlorophenyl) sulfamoyl]- $N$-(2-methyl5-nitrophenyl)-4-nitrobenzamide) was found to be highly active having fourfold inhibitory potential against $\alpha$-glucosidase and around six times inhibitory activity against $\alpha$-amylase in comparison to standard drug 


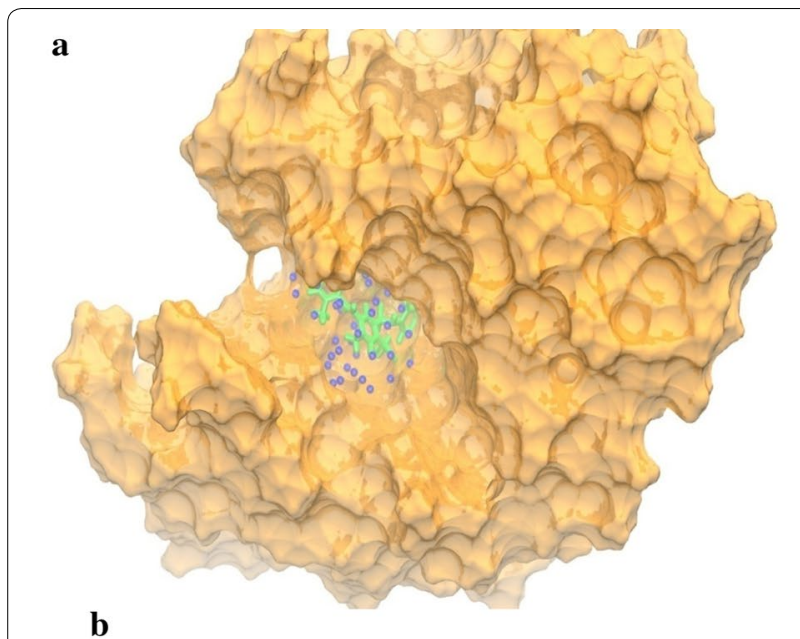

b

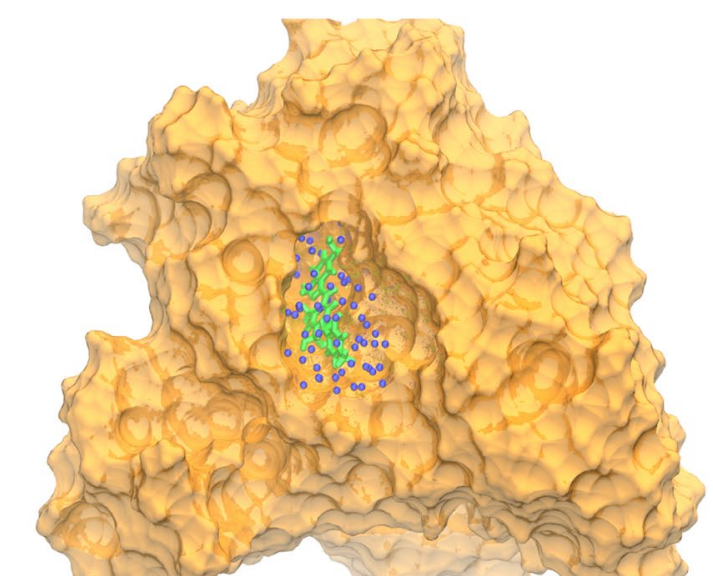

Fig. 5 a Active site of modeled protein of S. cerevisiae a-glucosidase (Golden color) with ligand 50 shown in green color, oxygen atom of water molecule as sphere in blue color. b Active site of a-amylase (Golden color) with ligand 50 shown in green color, oxygen atom of water molecule as sphere in blue color

acarbose. Molecular docking results of antidiabetic study showed reasonable dock score and binding interactions of synthesized molecules with their respective targets. Analysis of RMSD of ligand protein complex during molecular dynamic simulations suggested stability of the most active compounds 50 in binding site of respective target proteins i.e. $\alpha$-glucosidase and $\alpha$-amylase enzymes. Prediction of computational drug like properties showed that most of synthesized compounds are safe with acceptable ADMET and druggable properties.

\section{Materials and methods}

\section{Chemicals}

The analytical grade chemicals and reagents were used as such in experiments without any purification. Decibel melting point apparatus was used for checking the melting point of the synthesized compounds and are reported as uncorrected. The silica gel-precoated aluminum sheets for thin-layer chromatography (TLC) were employed to keep a vigil of the reaction progress. FT-IR (Diffuse Reflectance Method (DRS) -8000A, Shimadzu, Japan) spectrophotometer was utilized for recording infrared spectra and the Bruker Avance III, $400 \mathrm{MHz}$ NMR spectrometer was employed for nuclear magnetic resonance spectra $\left({ }^{1} \mathrm{H}\right.$ NMR, ${ }^{13} \mathrm{C}$ NMR; Chemical shift $\delta$ valuesppm). $\alpha$-Glucosidase from Saccharomyces cerevisiae (EC 3.2.1.20, Sigma Aldrich) and $\alpha$-amylase from malt (232588-1, HiMedia) have been used for in vitro studies.

\section{General procedure for synthesis}

of 2-chloro-5-[(4-chlorophenyl)sulfamoyl]- $\mathrm{N}$-(alkyl/

aryl)-4-nitrobenzamide (5a-5v)

Synthesis of 2-chloro-5-(chlorosulfonyl)-4-nitro benzoic acid

(2)

Compound 2 was synthesized from 2-chloro-4-nitro benzoic acid (1) as previously reported method in literature [32].

\section{Synthesis of 2-chloro-5-[(4-chlorophenyl) sulfamoyl]-4-nitrobenzoic acid (3)}

2-Chloro-5-(chlorosulfonyl)-4-nitrobenzoic acid (1 g, $0.003 \mathrm{~mol})$ was refluxed with $\mathrm{p}$-nitro aniline $(0.003 \mathrm{~mol})$ using dimethyl formamide as solvent, till the completion of reaction [34]. The reaction progress was monitored by TLC. The reaction mixture was cooled and yielded precipitates were washed and recrystallized.

\section{Synthesis of 2-chloro-5-[(4-chlorophenyl)sulfamoyl]-N-(alkyl) aryl)-4-nitrobenzamide (5a-5o)}

Compound $3(0.5 \mathrm{~g}, 0.0012 \mathrm{~mol})$ was further treated with excess of thionyl chloride in presence of catalytic amount of DMF with calcium chloride $\left(\mathrm{CaCl}_{2}\right)$ guard tube to get 2-chloro-5-[(4-chlorophenyl)sulfamoyl]-4-nitrobenzoylchloride (4). Compound 4 was dissolved in DMF and refluxed with anilines/amines/heterocyclic amines to get the desired products in appropriate yield [41]. After refluxing, mixture was cooled and poured on crushed ice, separated product was filtered and washed with dilute $\mathrm{HCl}$ and dried.

\section{Physicochemical and spectral characterization 2-Chloro-5-[(4-chlorophenyl) sulfamoyl]-N-(4-methylphenyl)-4-nitrobenzamide (5a)}

\% Yield: 37.70; m.p.: $90-92{ }^{\circ} \mathrm{C}$; $\mathrm{R}_{\mathrm{f}}$ : 0.81 (Chloroform); FTIR $(\mathrm{KBr}): v_{\max }\left(\mathrm{cm}^{-1}\right): 3502.79(\mathrm{~N}-\mathrm{H}$ str.), $3171.70(\mathrm{C}-\mathrm{H}$ str., Ar), 2977.30, 2889.01 (C-H str., Aliphatic), 1641.45 ( $\mathrm{C}=\mathrm{O}$ ), 1600.41 ( $\mathrm{N}-\mathrm{H}$ bend), 1586.48 (asym. $\mathrm{NO}_{2}$ str.), 1349.25 (sym. $\mathrm{NO}_{2}$ str.), 1315.47 (asym. $\mathrm{SO}_{2}$ str.), 1157.31 (sym. $\mathrm{SO}_{2}$ str.), $733.44 \quad(\mathrm{C}-\mathrm{Cl}) ;{ }^{1} \mathrm{HNMR}(300 \mathrm{MHz}$, DMSO- $\mathrm{d}_{6}$ ), $\delta$ ppm: 2.15 (s, 3H, $\left.\mathrm{CH}_{3}\right), 4.01$ (s, 1H, NH), 
6.78-6.80 (d, $2 \mathrm{H}, \mathrm{CH}$ of $\mathrm{C}_{3}, \mathrm{C}_{5}$ of $-\mathrm{CONH}-\mathrm{C}_{6} \mathrm{H}_{5} \mathrm{CH}_{3}-$ ), 7.11-7.13 (d, $2 \mathrm{H}, \mathrm{CH}$ of $\mathrm{C}_{2}, \mathrm{C}_{6}$ of $-\mathrm{CONH}-\mathrm{C}_{6} \mathrm{H}_{5} \mathrm{CH}_{3}-$ ), $7.60\left(\mathrm{~s}, 1 \mathrm{H}, \mathrm{CH}\right.$ of $\mathrm{C}_{6}$ of $\left.\mathrm{ClNO}_{2} \mathrm{C}_{6} \mathrm{H}_{2} \mathrm{CONH}-\right)$, 7.88-7.89 (d, $2 \mathrm{H}, \mathrm{CH}$ of $\mathrm{C}_{2}$ and $\mathrm{C}_{6}$ of $\left.\mathrm{ClC}_{6} \mathrm{H}_{4} \mathrm{NH}\right), 8.23(\mathrm{~s}, 1 \mathrm{H}, \mathrm{CH}$ of $\mathrm{C}_{3}$ of $\mathrm{ClNO}_{2} \mathrm{C}_{6} \mathrm{H}_{2} \mathrm{CONH}-$ ), 8.42-8.43 (d, $2 \mathrm{H}, \mathrm{CH}$ of $\mathrm{C}_{3}$ and $\mathrm{C}_{5}$ of $\left.\mathrm{ClC}_{6} \mathrm{H}_{4} \mathrm{NH}\right), 10.69(\mathrm{~s}, 1 \mathrm{H}, \mathrm{NH}) ;{ }^{13} \mathrm{CNMR}$ (300 MHz, DMSO-d $\left.{ }_{6}\right), \delta$ ppm: $163.59(\mathrm{C}=\mathrm{O}), 148.75$ (C-S), $142.92\left(\mathrm{C}-\mathrm{NO}_{2}\right), 136.44(\mathrm{C}-\mathrm{NH}), 133.79(\mathrm{C}-\mathrm{Cl})$, $131.62,130.79,130.34,129.71,125.76,123.26,120.15$, $119.55,117.91,21.00$.

\section{2-Chloro-5-[(4-chlorophenyl) sulfamoyl]-N-(3-methylphenyl)-4-nitrobenzamide (5b)}

\% Yield: 50.81; m.p.: $102-104{ }^{\circ} \mathrm{C}$; $\mathrm{R}_{\mathrm{f}}: 0.82$ (H:E- 8:2); FTIR (KBr): $v_{\max }\left(\mathrm{cm}^{-1}\right): 3502.97(\mathrm{~N}-\mathrm{H}$ str.), 3117.98 (C-H str., Ar), 2982.94, 2882.00 (C-H str., Aliphatic), $1621.03(\mathrm{C}=\mathrm{O}), 1602.20$ ( $\mathrm{N}-\mathrm{H}$ bend), 1544.11 (asym. $\mathrm{NO}_{2}$ str.), 1370.45 (asym. $\mathrm{SO}_{2}$ str.), 1340.55 (sym. $\mathrm{NO}_{2}$ str.), 1170.07 (sym. $\mathrm{SO}_{2}$ str.), 766.16 (C-Cl); ${ }^{1} \mathrm{HNMR}$ (300 MHz, DMSO-d $\left.\mathrm{d}_{6}\right), \delta \mathrm{ppm}: 2.35\left(\mathrm{~s}, 3 \mathrm{H}, \mathrm{CH}_{3}\right), 3.92(\mathrm{~s}$, $1 \mathrm{H}, \mathrm{NH}), 5.48\left(\mathrm{~s}, 1 \mathrm{H}, \mathrm{CH}\right.$ of $\mathrm{C}_{2}-\mathrm{CONH}-\mathrm{C}_{6} \mathrm{H}_{5} \mathrm{CH}_{3}-$ ), 6.88 (s, $1 \mathrm{H}, \mathrm{CH}$ of $\mathrm{C}_{6}$ of $\mathrm{ClNO}_{2} \mathrm{C}_{6} \mathrm{H}_{2} \mathrm{CONH}-$ ), 7.10-7.12 (d, $2 \mathrm{H}, \mathrm{CH}$ of $\mathrm{C}_{2}$ and $\mathrm{C}_{6}$ of $\left.\mathrm{ClC}_{6} \mathrm{H}_{4} \mathrm{NH}\right), 7.19(\mathrm{~s}, 1 \mathrm{H}, \mathrm{CH}$ of $\mathrm{C}_{3}$ of $\mathrm{ClNO}_{2} \mathrm{C}_{6} \mathrm{H}_{2} \mathrm{CONH}-$ ), 7.23-7.25 (d, $1 \mathrm{H}, \mathrm{CH}$ of $\mathrm{C}_{6}$ of $\left.-\mathrm{CONH}-\mathrm{C}_{6} \mathrm{H}_{5} \mathrm{CH}_{3}-\right), 7.35-7.40\left(\mathrm{~m}, 2 \mathrm{H}, \mathrm{CH}\right.$ of $\mathrm{C}_{4}$, $\left.\mathrm{C}_{5}-\mathrm{CONH}-\mathrm{C}_{6} \mathrm{H}_{5} \mathrm{CH}_{3}-\right), 7.51-7.53\left(\mathrm{~d}, 2 \mathrm{H}, \mathrm{CH}\right.$ of $\mathrm{C}_{3}$ and $\mathrm{C}_{5}$ of $\left.\mathrm{ClC}_{6} \mathrm{H}_{4} \mathrm{NH}\right), 10.31(\mathrm{~s}, 1 \mathrm{H}, \mathrm{NH}) ;{ }^{13} \mathrm{CNMR}(300 \mathrm{MHz}$, DMSO-d $\left.{ }_{6}\right), \delta$ ppm: $168.51(\mathrm{C}=\mathrm{O}), 151.75(\mathrm{C}-\mathrm{S}), 143.40$ $\left(\mathrm{C}-\mathrm{NO}_{2}\right), 139.92(\mathrm{C}-\mathrm{NH}), 138.59(\mathrm{C}-\mathrm{Cl}), 132.07,130.56$, 130.11, 129.23, 128.68, 124.09, 120.89, 119.21, 115.21, 21.41 .

\section{2-Chloro-5-[(4-chlorophenyl) sulfamoyl]- $\mathrm{N}$-(2-methylphenyl)-4-nitrobenzamide (5c)}

\% Yield: 84.91; m.p.: 88-90 ${ }^{\circ} \mathrm{C}$; $\mathrm{R}_{\mathrm{f}}: 0.75$ (Chloroform); FTIR $(\mathrm{KBr}): v_{\max }\left(\mathrm{cm}^{-1}\right): 3354.96(\mathrm{~N}-\mathrm{H}$ str.), $3197.07(\mathrm{C}-\mathrm{H}$ str., Ar), 2915.46, 2837.25 (C-H str., Aliphatic), 1602.25 $\left(\mathrm{C}=\mathrm{O}\right.$ ), 1578.76 ( $\mathrm{N}-\mathrm{H}$ bend), 1511.25 (asym. $\mathrm{NO}_{2}$ str.), 1374.26 (asym. $\mathrm{SO}_{2}$ str.),1348.27 (sym. $\mathrm{NO}_{2}$ str.), 1146.44 (sym. $\mathrm{SO}_{2}$ str.), 753.00 (C-Cl); ${ }^{1} \mathrm{HNMR}(300 \mathrm{MHz}$, DMSO- $\left.\mathrm{d}_{6}\right), \delta$ ppm: $2.35\left(\mathrm{~s}, 3 \mathrm{H}, \mathrm{CH}_{3}\right), 3.45(\mathrm{~s}, 1 \mathrm{H}, \mathrm{NH})$, 6.58-6.60 (d, $1 \mathrm{H}, \mathrm{CH}$ of $\left.\mathrm{C}_{3}-\mathrm{CONH}-\mathrm{C}_{6} \mathrm{H}_{5} \mathrm{CH}_{3}-\right)$, 7.26-7.33 (t, $2 \mathrm{H}, \mathrm{CH}$ of $\mathrm{C}_{4}, \mathrm{C}_{5}$ of $-\mathrm{CONH}-\mathrm{C}_{6} \mathrm{H}_{5} \mathrm{CH}_{3}-$ ), 7.40-7.41 (d, $\mathrm{H}, \mathrm{CH}$ of $\left.\mathrm{C}_{6}-\mathrm{CONH}-\mathrm{C}_{6} \mathrm{H}_{5} \mathrm{CH}_{3}-\right), 7.81$ (s, $1 \mathrm{H}, \mathrm{CH}$ of $\mathrm{C}_{6}$ of $\mathrm{ClNO}_{2} \mathrm{C}_{6} \mathrm{H}_{2} \mathrm{CONH}-$ ), 8.00-8.02 (d, $2 \mathrm{H}, \mathrm{CH}$ of $\mathrm{C}_{2}$ and $\mathrm{C}_{6}$ of $\left.\mathrm{ClC}_{6} \mathrm{H}_{4} \mathrm{NH}\right), 8.36-8.37(\mathrm{~d}, 2 \mathrm{H}$, $\mathrm{CH}$ of $\mathrm{C}_{3}$ and $\mathrm{C}_{5}$ of $\left.\mathrm{ClC}_{6} \mathrm{H}_{4} \mathrm{NH}\right), 8.51\left(\mathrm{~s}, 1 \mathrm{H}, \mathrm{CH}\right.$ of $\mathrm{C}_{3}$ of $\left.\mathrm{ClNO}_{2} \mathrm{C}_{6} \mathrm{H}_{2} \mathrm{CONH}-\right), 10.31(\mathrm{~s}, 1 \mathrm{H}, \mathrm{NH}) ;{ }^{13} \mathrm{CNMR}$ (300 MHz, DMSO-d $\left.\mathrm{d}_{6}\right), \delta \mathrm{ppm}: 162.32(\mathrm{C}=\mathrm{O}), 153.39$ $(\mathrm{C}-\mathrm{S}), 142.32\left(\mathrm{C}-\mathrm{NO}_{2}\right), 136.24(\mathrm{C}-\mathrm{NH}), 133.93(\mathrm{C}-\mathrm{Cl})$, $131.57,129.24,127.88,125.93,123.22,120.56,117.54$, $115.14,17.72$.

\section{2-Chloro-5-[(4-chlorophenyl)} sulfamoyl]-N-(4-methoxyphenyl)-4-nitrobenzamide (5d)

\% Yield: 88.69; m.p.: 150-152 ${ }^{\circ} \mathrm{C}$; $\mathrm{R}_{\mathrm{f}}$ : 0.23 (Chloroform); FTIR (KBr): $v_{\max }\left(\mathrm{cm}^{-1}\right): 3438.05$ (N-H str.), 3083.26 (C-H str., Ar), $1614.01 \quad(\mathrm{C}=\mathrm{O}), \quad 1594.19$ ( $\mathrm{N}-\mathrm{H}$ bend), 1555.62 (asym. $\mathrm{NO}_{2}$ str.), 1352.32 (sym. $\mathrm{NO}_{2}$ str.), 1304.87 (asym. $\mathrm{SO}_{2}$ str.), 1261.51 (C-O-C str.), 1175.58 (sym. $\mathrm{SO}_{2}$ str.), 727.73 (C-Cl); ${ }^{1} \mathrm{HNMR}$ $\left(300 \mathrm{MHz}, \mathrm{DMSO}-\mathrm{d}_{6}\right), \delta: 3.38\left(\mathrm{~s}, 3 \mathrm{H}, \mathrm{OCH}_{3}\right.$ of $\left.\mathrm{CONH}-\mathrm{C}_{6} \mathrm{H}_{5} \mathrm{OCH}_{3}-\right), 3.89(\mathrm{~s}, 1 \mathrm{H}, \mathrm{NH}), 7.02-7.03(\mathrm{~d}$, $2 \mathrm{H}, \mathrm{CH}$ of $\mathrm{C}_{3}, \mathrm{C}_{5}$ of $\left.-\mathrm{CONH}-\mathrm{C}_{6} \mathrm{H}_{5} \mathrm{OCH}_{3}-\right)$, 7.34-7.37 (d, $2 \mathrm{H}, \mathrm{CH}$ of $\mathrm{C}_{2}, \mathrm{C}_{6}$ of $-\mathrm{CONH}-\mathrm{C}_{6} \mathrm{H}_{5} \mathrm{OCH}_{3}-$ ), 7.52 (s, $1 \mathrm{H}, \mathrm{CH}$ of $\mathrm{C}_{6}$ of $\mathrm{ClNO}_{2} \mathrm{C}_{6} \mathrm{H}_{2} \mathrm{CONH}-$ ), 7.81-7.83 (d, $2 \mathrm{H}, \mathrm{CH}$ of $\mathrm{C}_{2}$ and $\mathrm{C}_{6}$ of $\left.\mathrm{ClC}_{6} \mathrm{H}_{4} \mathrm{NH}\right), 8.09-8.11(\mathrm{~d}, 2 \mathrm{H}$, $\mathrm{CH}$ of $\mathrm{C}_{3}$ and $\mathrm{C}_{5}$ of $\left.\mathrm{ClC}_{6} \mathrm{H}_{4} \mathrm{NH}\right), 8.50\left(\mathrm{~s}, 1 \mathrm{H}, \mathrm{CH}\right.$ of $\mathrm{C}_{3}$ of $\left.\mathrm{ClNO}_{2} \mathrm{C}_{6} \mathrm{H}_{2} \mathrm{CONH}-\right)$, $10.32(\mathrm{~s}, 1 \mathrm{H}, \mathrm{NH}) ;{ }^{13} \mathrm{CNMR}$ (300 MHz, DMSO-d ${ }_{6}$ ), $\delta$ ppm: $164.63(\mathrm{C}=\mathrm{O}), 154.30$ (C-S), $144.57\left(\mathrm{C}-\mathrm{NO}_{2}\right), 138.48(\mathrm{C}-\mathrm{NH}), 136.24(\mathrm{C}-\mathrm{Cl})$, $131.58,129.95,128.12,126.09,124.46,123.24,120.20$, 32.90 .

\section{2-Chloro-5-[(4-chlorophenyl) sulfamoyl]-N-(2-methoxyphenyl)-4-nitrobenzamide (5e)}

\% Yield: 85.30; m.p.: 164-166 ${ }^{\circ} \mathrm{C}$; $\mathrm{R}_{\mathrm{f}}: 0.53$ (B:EA-7:3); FTIR (KBr): $v_{\max }\left(\mathrm{cm}^{-1}\right): 3447.82(\mathrm{~N}-\mathrm{H}$ str.), 3012.86 (C-H str., Ar), $1682.45(\mathrm{C}=\mathrm{O}), 1597.64$ ( $\mathrm{N}-\mathrm{H}$ bend), 1530.54 (asym. $\mathrm{NO}_{2}$ str.), 1378.16 (sym. $\mathrm{NO}_{2}$ str.), 1307.76 (asym. $\mathrm{SO}_{2}$ str.), 1252.68 (C-O-C str.), 1174.67 (sym. $\mathrm{SO}_{2}$ str.), 752.65 (C-Cl); ${ }^{1} \mathrm{HNMR}\left(300 \mathrm{MHz}, \mathrm{DMSO}-\mathrm{d}_{6}\right.$ ), $\delta$ ppm: 3.38 (s, 3H, $\mathrm{OCH}_{3}$ ), $3.89(\mathrm{~s}, 1 \mathrm{H}, \mathrm{NH}), 7.07-7.09$ (d, $1 \mathrm{H}, \mathrm{CH}$ of $\mathrm{C}_{3}-\mathrm{CONH}-\mathrm{C}_{6} \mathrm{H}_{5} \mathrm{OCH}_{3}-$ ), 7.27.7.33 (m, $3 \mathrm{H}, \mathrm{CH}$ of $\mathrm{C}_{4}, \mathrm{C}_{5}, \mathrm{C}_{6}$ of $\left.-\mathrm{CONH}-\mathrm{C}_{6} \mathrm{H}_{5} \mathrm{OCH}_{3}-\right), 7.52$ (s, $1 \mathrm{H}, \mathrm{CH}$ of $\mathrm{C}_{6}$ of $\mathrm{ClNO}_{2} \mathrm{C}_{6} \mathrm{H}_{2} \mathrm{CONH}-$ ), 7.81-7.82 (d, $2 \mathrm{H}, \mathrm{CH}$ of $\mathrm{C}_{2}$ and $\mathrm{C}_{6}$ of $\left.\mathrm{ClC}_{6} \mathrm{H}_{4} \mathrm{NH}\right), 8.28-8.30(\mathrm{~d}, 2 \mathrm{H}$, $\mathrm{CH}$ of $\mathrm{C}_{3}$ and $\mathrm{C}_{5}$ of $\left.\mathrm{ClC}_{6} \mathrm{H}_{4} \mathrm{NH}\right), 8.49$ (s, $1 \mathrm{H}, \mathrm{CH}$ of $\mathrm{C}_{3}$ of $\left.\mathrm{ClNO}_{2} \mathrm{C}_{6} \mathrm{H}_{2} \mathrm{CONH}-\right), 10.48(\mathrm{~s}, 1 \mathrm{H}, \mathrm{NH}) ;{ }^{13} \mathrm{CNMR}$ (300 MHz, DMSO-d $\left.\mathrm{d}_{6}\right), \delta$ ppm: $164.21(\mathrm{C}=\mathrm{O}), 157.32$ (C-S), $145.07\left(\mathrm{C}-\mathrm{NO}_{2}\right), 139.07(\mathrm{C}-\mathrm{NH}), 136.16(\mathrm{C}-\mathrm{Cl})$, $131.34,129.45,128.24,127.14,125.18,121.68,121.51$, $120.55,35.60$.

\section{$\mathrm{N}$-(4-Bromophenyl)-2-chloro-5-[(4-chlorophenyl) sulfamoyl]-4-nitrobenzamide (5f)}

\% Yield: 91.30; m.p.: 200-202 ${ }^{\circ} \mathrm{C}$; $\mathrm{R}_{\mathrm{f}}$ : 0.56 (Chloroform); FTIR (KBr): $v_{\max }\left(\mathrm{cm}^{-1}\right): 3392.85$ (N-H str.), 3012.55 (C-H str., Ar), $1614.45(\mathrm{C}=\mathrm{O}), 1591.36$ (N-H bend), 1562.37 (asym. $\mathrm{NO}_{2}$ str.), 1353.50 (sym. $\mathrm{NO}_{2}$ str.), 1308.72 (asym. $\mathrm{SO}_{2}$ str.), 1145.63 (sym. $\mathrm{SO}_{2}$ str.), $732.07(\mathrm{C}-\mathrm{Cl}), 691.49$ (C-Br); ${ }^{1} \mathrm{HNMR}(300 \mathrm{MHz}$, DMSO- $\left.\mathrm{d}_{6}\right), \delta$ ppm: $3.60(\mathrm{~s}, 1 \mathrm{H}, \mathrm{NH}), 7.46(\mathrm{~s}, 1 \mathrm{H}, \mathrm{CH}$ of $\mathrm{C}_{6}$ of $\mathrm{ClNO}_{2} \mathrm{C}_{6} \mathrm{H}_{2} \mathrm{CONH}-$ ), 7.54-7.55 (d, $2 \mathrm{H}, \mathrm{CH}$ of $\mathrm{C}_{2}$ and $\mathrm{C}_{6}$ of $\left.\mathrm{ClC}_{6} \mathrm{H}_{4} \mathrm{NH}\right), 8.00-8.02(\mathrm{~d}, 2 \mathrm{H}, \mathrm{CH}$ of 
$\mathrm{C}_{2}, \mathrm{C}_{6}$ of $\left.-\mathrm{CONH}-\mathrm{C}_{6} \mathrm{H}_{5} \mathrm{Br}-\right)$, 8.24-8.26 (d, $2 \mathrm{H}, \mathrm{CH}$ of $\mathrm{C}_{3}$ and $\mathrm{C}_{5}$ of $\left.\mathrm{ClC}_{6} \mathrm{H}_{4} \mathrm{NH}\right), 8.36-8.37(\mathrm{~d}, 2 \mathrm{H}, \mathrm{CH}$ of $\left.\mathrm{C}_{3}, \mathrm{C}_{5}-\mathrm{CONH}-\mathrm{C}_{6} \mathrm{H}_{5} \mathrm{CH}_{3}-\right), 8.51\left(\mathrm{~s}, 1 \mathrm{H}, \mathrm{CH}\right.$ of $\mathrm{C}_{3}$ of $\left.\mathrm{ClNO}_{2} \mathrm{C}_{6} \mathrm{H}_{2} \mathrm{CONH}-\right), 10.55(\mathrm{~s}, 1 \mathrm{H}, \mathrm{NH}) ;{ }^{13} \mathrm{CNMR}$ (300 MHz, DMSO-d $\left.{ }_{6}\right), \delta$ ppm: $166.34(\mathrm{C}=\mathrm{O}), 158.33$ (C-S), $144.35\left(\mathrm{C}-\mathrm{NO}_{2}\right), 140.21(\mathrm{C}-\mathrm{NH}), 135.49(\mathrm{C}-\mathrm{Cl})$, 132.90, 130.58, 129.89, 129.21, 128.24, 127.08, 120.18 .

\section{N-(3-Bromophenyl)-2-chloro-5-[(4-chlorophenyl) sulfamoyl]-4-nitrobenzamide (5g)}

\% Yield: 44.92; m.p.: $181-183{ }^{\circ} \mathrm{C}$; $\mathrm{R}_{\mathrm{f}}$ : 0.73 (Chloroform); FTIR (KBr): $v_{\max }\left(\mathrm{cm}^{-1}\right): 3502.79(\mathrm{~N}-\mathrm{H}$ str.), 3058.19 (C-H str., Ar), $1614.45(\mathrm{C}=\mathrm{O}), 1588.41(\mathrm{~N}-\mathrm{H}$ bend), 1566.61 (asym. $\mathrm{NO}_{2}$ str.), 1372.38 (asym. $\mathrm{SO}_{2}$ str.), 1302.95 (sym. $\mathrm{NO}_{2}$ str.), 1175.63 (sym. $\mathrm{SO}_{2}$ str.), $778.76(\mathrm{C}-\mathrm{Cl}), 675.80(\mathrm{C}-\mathrm{Br}) ;{ }^{1} \mathrm{HNMR}(300 \mathrm{MHz}$, DMSO-d $\left.\mathrm{d}_{6}\right), \delta$ ppm: $3.71(\mathrm{~s}, 1 \mathrm{H}, \mathrm{NH}), 7.37(\mathrm{~s}, 1 \mathrm{H}, \mathrm{CH}$ of $\mathrm{C}_{6}$ of $\left.\mathrm{ClNO}_{2} \mathrm{C}_{6} \mathrm{H}_{2} \mathrm{CONH}-\right), 7.51$ (s, $1 \mathrm{H}, \mathrm{CH}$ of $\left.\mathrm{CONH}-\mathrm{C}_{6} \mathrm{H}_{5} \mathrm{Br}-\right), 7.71-7.80\left(\mathrm{~d}, 2 \mathrm{H}, \mathrm{CH}\right.$ of $\mathrm{C}_{2}$ and $\mathrm{C}_{6}$ of $\left.\mathrm{ClC}_{6} \mathrm{H}_{4} \mathrm{NH}-\right)$, 7.93-7.98 (m, 3H, CH C $\mathrm{C}_{4}, \mathrm{C}_{5}$ and $\mathrm{C}_{6}$ of $\left.-\mathrm{CONH}-\mathrm{C}_{6} \mathrm{H}_{5} \mathrm{Br}-\right), 8.21-8.23(\mathrm{~d}, 2 \mathrm{H}, \mathrm{CH}$ of $\mathrm{C}_{3}$ and $\mathrm{C}_{5}$ of $\mathrm{ClC}_{6} \mathrm{H}_{4} \mathrm{NH}$ ), $8.48\left(\mathrm{~s}, 1 \mathrm{H}, \mathrm{CH}\right.$ of $\mathrm{C}_{3}$ of $\left.\mathrm{ClNO}_{2} \mathrm{C}_{6} \mathrm{H}_{2} \mathrm{CONH}-\right), 10.40$ (s, $\left.1 \mathrm{H}, \quad \mathrm{NH}\right) ;{ }^{13} \mathrm{CNMR}$ (300 MHz, DMSO-d $\left.{ }_{6}\right), \delta$ ppm: $165.33(\mathrm{C}=\mathrm{O}), 157.35$ $(\mathrm{C}-\mathrm{S}), 143.24\left(\mathrm{C}-\mathrm{NO}_{2}\right), 139.51(\mathrm{C}-\mathrm{NH}), 136.54(\mathrm{C}-\mathrm{Cl})$, $133.05,130.77,129.10,128.39,128.17,127.63,126.71$, $126.12,121.49$.

\section{$N$-(2-Bromophenyl)-2-chloro-5-[(4-chlorophenyl) sulfamoyl]-4-nitrobenzamide (5h)}

\% Yield: 55.07; m.p.: $180-182{ }^{\circ} \mathrm{C}$; $\mathrm{R}_{\mathrm{f}}$ : 0.70 (Chloroform); FTIR (KBr): $v_{\max }\left(\mathrm{cm}^{-1}\right): 3392.85(\mathrm{~N}-\mathrm{H}$ str.), 3028.29 (C-H str., Ar), $1614.62(\mathrm{C}=\mathrm{O}), 1594.19(\mathrm{~N}-\mathrm{H}$ bend), 1565.96 (asym. $\mathrm{NO}_{2}$ str.), 1349.23 (sym. $\mathrm{NO}_{2}$ str.), 1377.20 (asym. $\mathrm{SO}_{2}$ str.), 1152.15 (sym. $\mathrm{SO}_{2}$ str.), 754.34 $(\mathrm{C}-\mathrm{Cl}), 661.15$ (C-Br); ${ }^{1} \mathrm{HNMR} \quad(300 \mathrm{MHz}, \mathrm{DMSO}-$ $\left.\mathrm{d}_{6}\right), \delta$ ppm: $3.83(\mathrm{~s}, 1 \mathrm{H}, \mathrm{NH}), 6.57-6.61(\mathrm{t}, 1 \mathrm{H}, \mathrm{CH}$ of $\mathrm{C}_{5}$ of $\left.-\mathrm{CONH}-\mathrm{C}_{6} \mathrm{H}_{5} \mathrm{Br}-\right)$, 6.90-6.92 (d, $1 \mathrm{H}, \mathrm{CH}$ of $\mathrm{C}_{6}$ $\left.-\mathrm{CONH}-\mathrm{C}_{6} \mathrm{H}_{5} \mathrm{Br}-\right), 7.12-7.14\left(\mathrm{t}, 1 \mathrm{H}, \mathrm{CH}\right.$ of $\mathrm{C}_{4}$ of $\left.\mathrm{CONH}-\mathrm{C}_{6} \mathrm{H}_{5} \mathrm{Br}-\right)$, 7.32-7.40 (d, $2 \mathrm{H}, \mathrm{CH}$ of $\mathrm{C}_{2}$ and $\mathrm{C}_{6}$ of $\left.\mathrm{ClC}_{6} \mathrm{H}_{4} \mathrm{NH}\right), 7.51-7.52\left(\mathrm{~d}, 1 \mathrm{H}, \mathrm{CH}\right.$ of $\mathrm{C}_{3}$ of $-\mathrm{CONH}-$ $\mathrm{C}_{6} \mathrm{H}_{5} \mathrm{Br}-$ ), 7.82 (s, $1 \mathrm{H}, \mathrm{CH}$ of $\mathrm{C}_{6}$ of $\mathrm{ClNO}_{2} \mathrm{C}_{6} \mathrm{H}_{2} \mathrm{CONH}-$ ), 8.16-8.18 (d, $2 \mathrm{H}, \mathrm{CH}$ of $\mathrm{C}_{3}$ and $\mathrm{C}_{5}$ of $\left.\mathrm{ClC}_{6} \mathrm{H}_{4} \mathrm{NH}\right), 8.50$ (s, $1 \mathrm{H}, \mathrm{CH}$ of $\mathrm{C}_{3}$ of $\left.\mathrm{ClNO}_{2} \mathrm{C}_{6} \mathrm{H}_{2} \mathrm{CONH}-\right), 10.39$ (s, $\left.1 \mathrm{H}, \mathrm{NH}\right)$; ${ }^{13} \mathrm{CNMR}\left(300 \mathrm{MHz}\right.$, DMSO-d $\left.{ }_{6}\right), \delta$ ppm: $167.04(\mathrm{C}=\mathrm{O})$, $156.56(\mathrm{C}-\mathrm{S}), 143.06\left(\mathrm{C}-\mathrm{NO}_{2}\right), 138.20(\mathrm{C}-\mathrm{NH}), 135.47$ (C-Cl), 135.07, 130.23, 129.04, 128.93, 126.13, 125.34, 122.21.

\section{2-Chloro-N-(3-chlorophenyl)-5-[(4-chlorophenyl) sulfamoyl]-4-nitrobenzamide (5i)}

\% Yield: 93.25; m.p.: $220-222{ }^{\circ} \mathrm{C}$; $\mathrm{R}_{\mathrm{f}}$ : 0.72 (B:EA- 7:3); FTIR (KBr): $v_{\max }\left(\mathrm{cm}^{-1}\right): 3455.53(\mathrm{~N}-\mathrm{H}$ str.), 3056.96
(C-H str., Ar), $1687.80(\mathrm{C}=\mathrm{O}), 1592.15(\mathrm{~N}-\mathrm{H}$ bend), 1542.11 (asym. $\mathrm{NO}_{2}$ str.), 1366.59 (sym. $\mathrm{NO}_{2}$ str.), 1308.72 (asym. $\mathrm{SO}_{2}$ str.), 1165.99 (sym. $\mathrm{SO}_{2}$ str.), 782.92 $\left(\mathrm{C}-\mathrm{Cl}\right.$ ); ${ }^{1} \mathrm{HNMR}\left(300 \mathrm{MHz}, \mathrm{DMSO}-\mathrm{d}_{6}\right), \delta \mathrm{ppm}: 3.39(\mathrm{~s}$, $1 \mathrm{H}, \mathrm{NH}), 7.51\left(\mathrm{~s}, 1 \mathrm{H}, \mathrm{CH}\right.$ of $\mathrm{C}_{6}$ of $\mathrm{ClNO}_{2} \mathrm{C}_{6} \mathrm{H}_{2} \mathrm{CONH}-$ ), 7.80-7.83 (d, 2H, $\mathrm{CH}$ of $\mathrm{C}_{2}$ and $\mathrm{C}_{6}$ of $\left.\mathrm{ClC}_{6} \mathrm{H}_{4} \mathrm{NH}\right), 8.01-$ $8.04\left(\mathrm{~m}, 3 \mathrm{H}, \mathrm{CH} \mathrm{C} \mathrm{C}_{4}, \mathrm{C}_{5}\right.$ and $\mathrm{C}_{6}$ of $-\mathrm{CONH}-\mathrm{C}_{6} \mathrm{H}_{5} \mathrm{Cl}-$ ), $8.23\left(\mathrm{~s}, 1 \mathrm{H}, \mathrm{CH}\right.$ of $\left.-\mathrm{CONH}-\mathrm{C}_{6} \mathrm{H}_{5} \mathrm{Cl}-\right), 8.30-8.32$ (d, $2 \mathrm{H}, \mathrm{CH}$ of $\mathrm{C}_{3}$ and $\mathrm{C}_{5}$ of $\left.\mathrm{ClC}_{6} \mathrm{H}_{4} \mathrm{NH}\right), 8.49(\mathrm{~s}, 1 \mathrm{H}, \mathrm{CH}$ of $\mathrm{C}_{3}$ of $\left.\mathrm{ClNO}_{2} \mathrm{C}_{6} \mathrm{H}_{2} \mathrm{CONH}-\right), 10.20(\mathrm{~s}, 1 \mathrm{H}, \mathrm{NH}) ;{ }^{13} \mathrm{CNMR}$ (300 MHz, DMSO-d $\left.\mathrm{d}_{6}\right), \delta \mathrm{ppm}: 167.04(\mathrm{C}=\mathrm{O}), 155.28$ (C-S), $145.02\left(\mathrm{C}-\mathrm{NO}_{2}\right), 139.44(\mathrm{C}-\mathrm{NH}), 136.10(\mathrm{C}-\mathrm{Cl})$, 132.12, 130.16, 129.12, 128.14, 127.33, 127.17, 126.39, 124.17.

\section{2-Chloro-N-(2-chlorophenyl)-5-[(4-chlorophenyl) sulfamoyl]-4-nitrobenzamide (5j)}

\% Yield: 87.71; m.p.: $176-178^{\circ} \mathrm{C}$; $\mathrm{R}_{\mathrm{f}}: 0.5$ (B:EA- 7:3); FTIR $(\mathrm{KBr}): v_{\max }\left(\mathrm{cm}^{-1}\right): 3337.42(\mathrm{~N}-\mathrm{H}$ str.), $3060.18(\mathrm{C}-\mathrm{H}$ str., Ar), $1665.56(\mathrm{C}=\mathrm{O}), 1592.43(\mathrm{~N}-\mathrm{H}$ bend $), 1533.43$ (asym. $\mathrm{NO}_{2}$ str.), 1377.20 (sym. $\mathrm{NO}_{2}$ str.), 1392.63 (asym. $\mathrm{SO}_{2}$ str.), 1173.70 (sym. $\mathrm{SO}_{2}$ str.), 755.22 (C-Cl); ${ }^{1} \mathrm{HNMR}$ (300 MHz, DMSO-d $\left.\mathrm{d}_{6}\right), \delta$ ppm: $3.89(\mathrm{~s}, 1 \mathrm{H}, \mathrm{NH}), 7.44(\mathrm{~s}$, $1 \mathrm{H}, \mathrm{CH}$ of $\mathrm{C}_{6}$ of $\mathrm{ClNO}_{2} \mathrm{C}_{6} \mathrm{H}_{2} \mathrm{CONH}-$ ), 7.85-7.90 (m, $3 \mathrm{H}, \mathrm{CH}$ of $\mathrm{C}_{4}, \mathrm{C}_{5}$ and $\left.\mathrm{C}_{6}-\mathrm{CONH}-\mathrm{C}_{6} \mathrm{H}_{5} \mathrm{Cl}-\right), 7.98-8.00$ (d, $2 \mathrm{H}, \mathrm{CH}$ of $\mathrm{C}_{2}$ and $\mathrm{C}_{6}$ of $\mathrm{ClC}_{6} \mathrm{H}_{4} \mathrm{NH}$ ), 8.21-8.22 (d, $2 \mathrm{H}, \mathrm{CH}$ of $\mathrm{C}_{3}$ and $\mathrm{C}_{5}$ of $\left.\mathrm{ClC}_{6} \mathrm{H}_{4} \mathrm{NH}\right), 8.31-8.33(\mathrm{~d}, 1 \mathrm{H}$, $\mathrm{CH}$ of $\mathrm{C}_{3}$ of $\left.-\mathrm{CONH}-\mathrm{C}_{6} \mathrm{H}_{5} \mathrm{Cl}-\right), 8.52\left(\mathrm{~s}, 1 \mathrm{H}, \mathrm{CH}\right.$ of $\mathrm{C}_{3}$ of $\left.\mathrm{ClNO}_{2} \mathrm{C}_{6} \mathrm{H}_{2} \mathrm{CONH}-\right), 10.19$ (s, $\left.1 \mathrm{H}, \mathrm{NH}\right) ;{ }^{13} \mathrm{CNMR}$ (300 MHz, DMSO-d $\left.\mathrm{d}_{6}\right), \delta$ ppm: 166.34 $(\mathrm{C}=\mathrm{O}), 157.02$ (C-S), $146.93\left(\mathrm{C}-\mathrm{NO}_{2}\right), 139.24(\mathrm{C}-\mathrm{NH}), 135.56(\mathrm{C}-\mathrm{Cl})$, $131.57,131.25,129.53,128.55,127.21,125.24,121.86$.

\section{2-Chloro-5-[(4-chlorophenyl) sulfamoyl]-4-nitro-N-(2-nitrophenyl)benzamide (5k)}

\% Yield: 44.61; m.p.: $150-152^{\circ} \mathrm{C}$; $\mathrm{R}_{\mathrm{f}}: 0.8$ (B:EA- 7:3); FTIR $(\mathrm{KBr}): v_{\max }\left(\mathrm{cm}^{-1}\right): 3524.01$ (N-H str.), $3198.03(\mathrm{C}-\mathrm{H}$ str., Ar), $1614.45(\mathrm{C}=\mathrm{O}), 1593.50(\mathrm{~N}-\mathrm{H}$ bend), 1563.33 (asym. $\mathrm{NO}_{2}$ str.), 1376.23 (asym. $\mathrm{SO}_{2}$ str.), 1347.30 (sym. $\mathrm{NO}_{2}$ str.), 1146.26 (sym. $\mathrm{SO}_{2}$ str.), 746.55 (C-Cl); ${ }^{1} \mathrm{HNMR}$ (300 MHz, DMSO-d $\left.{ }_{6}\right), \delta$ ppm: $3.64(\mathrm{~s}, 1 \mathrm{H}, \mathrm{NH}), 7.26-$ $7.28\left(\mathrm{~d}, 1 \mathrm{H}, \mathrm{CH}\right.$ of $\mathrm{C}_{6}$ of $\left.-\mathrm{CONH}-\mathrm{C}_{6} \mathrm{H}_{5} \mathrm{NO}_{2}-\right)$, 7.46$7.48\left(\mathrm{~d}, 1 \mathrm{H}, \mathrm{CH}\right.$ of $\mathrm{C}_{3}$ of $\left.-\mathrm{CONH}-\mathrm{C}_{6} \mathrm{H}_{5} \mathrm{NO}_{2}-\right), 7.65$ (s, $1 \mathrm{H}, \mathrm{CH}$ of $\mathrm{C}_{6}$ of $\mathrm{ClNO}_{2} \mathrm{C}_{6} \mathrm{H}_{2} \mathrm{CONH}-$ ), 7.81-7.82 (d, $2 \mathrm{H}, \mathrm{CH}$ of $\mathrm{C}_{2}$ and $\mathrm{C}_{6}$ of $\left.\mathrm{ClC}_{6} \mathrm{H}_{4} \mathrm{NH}\right), 7.90-7.96(\mathrm{~m}, 2 \mathrm{H}$, $\mathrm{CH}$ of $\mathrm{C}_{4}, \mathrm{C}_{5}$ of $\left.-\mathrm{CONH}-\mathrm{C}_{6} \mathrm{H}_{5} \mathrm{NO}_{2}-\right), 8.16-8.19(\mathrm{~d}, 2 \mathrm{H}$, $\mathrm{CH}$ of $\mathrm{C}_{3}$ and $\mathrm{C}_{5}$ of $\left.\mathrm{ClC}_{6} \mathrm{H}_{4} \mathrm{NH}\right), 8.50$ (s, $1 \mathrm{H}, \mathrm{CH}$ of $\mathrm{C}_{3}$ of $\left.\mathrm{ClNO}_{2} \mathrm{C}_{6} \mathrm{H}_{2} \mathrm{CONH}-\right), 10.30(\mathrm{~s}, 1 \mathrm{H}, \mathrm{NH}) ;{ }^{13} \mathrm{CNMR}$ (300 MHz, DMSO-d $\left.{ }_{6}\right), \delta$ ppm: $167.03(\mathrm{C}=\mathrm{O}), 156.04$ $(\mathrm{C}-\mathrm{S}), 149.28\left(\mathrm{C}-\mathrm{NO}_{2}\right), 141.14(\mathrm{C}-\mathrm{NH}), 137.43(\mathrm{C}-\mathrm{Cl})$, $135.29,133.38,132.21,130.67,130.22,129.18,128.15$, 126.02 . 
2-Chloro-N-(3-chloro-2-methylphenyl)-5-[(4-chlorophenyl) sulfamoyl]-4-nitrobenzamide (5I)

\% Yield: 57.62; m.p.: 212-214 ${ }^{\circ} \mathrm{C}$; $\mathrm{R}_{\mathrm{f}}$ : 0.65 (B:EA- 7:3); FTIR (KBr): $v_{\max }\left(\mathrm{cm}^{-1}\right)$ : $3447.82(\mathrm{~N}-\mathrm{H}$ str.), 3096.77 (C-H str., Ar), 2947.05, 2885.31 (C-H str., Aliphatic), 1692.29 ( $\mathrm{C}=\mathrm{O}), 1592.79$ ( $\mathrm{N}-\mathrm{H}$ bend), 1531.51 (asym. $\mathrm{NO}_{2}$ str.), 1380.09 (asym. $\mathrm{SO}_{2}$ str.), 1306.80 (sym. $\mathrm{NO}_{2}$ str.), 1174.67 (sym. $\mathrm{SO}_{2}$ str.), 772.81 (C$\mathrm{Cl}) ;{ }^{1} \mathrm{HNMR}\left(300 \mathrm{MHz}, \mathrm{DMSO}-\mathrm{d}_{6}\right), \delta \mathrm{ppm:} 2.26$ (s, $\left.\mathrm{H}, \mathrm{CH}_{3}\right), 3.45(\mathrm{~s}, 1 \mathrm{H}, \mathrm{NH}), 7.24-7.30(\mathrm{~m}, 2 \mathrm{H}, \mathrm{CH} \mathrm{C}$, $\mathrm{C}_{5}$ andC $_{6}$ of $\left.-\mathrm{CONH}-\mathrm{C}_{6} \mathrm{H}_{5} \mathrm{CH}_{3} \mathrm{Cl}-\right), 7.63(\mathrm{~s}, 1 \mathrm{H}$, $\mathrm{CH}$ of $\mathrm{C}_{6}$ of $\left.\mathrm{ClNO}_{2} \mathrm{C}_{6} \mathrm{H}_{2} \mathrm{CONH}-\right), 7.81-7.82(\mathrm{~d}, 2 \mathrm{H}$, $\mathrm{CH}$ of $\mathrm{C}_{2}$ and $\mathrm{C}_{6}$ of $\left.\mathrm{ClC}_{6} \mathrm{H}_{4} \mathrm{NH}\right), 8.28-8.30(\mathrm{~d}, 2 \mathrm{H}$, $\mathrm{CH}$ of $\mathrm{C}_{3}$ and $\mathrm{C}_{5}$ of $\left.\mathrm{ClC}_{6} \mathrm{H}_{4} \mathrm{NH}\right), 8.58\left(\mathrm{~s}, 1 \mathrm{H}, \mathrm{CH}\right.$ of $\mathrm{C}_{3}$ of $\left.\mathrm{ClNO}_{2} \mathrm{C}_{6} \mathrm{H}_{2} \mathrm{CONH}-\right), 10.59$ (s, $\left.1 \mathrm{H}, \mathrm{NH}\right) ;{ }^{13} \mathrm{CNMR}$ (300 MHz, DMSO-d ${ }_{6}$ ), $\delta$ ppm: $165.37(\mathrm{C}=\mathrm{O}), 158.36$ (C-S), $147.85\left(\mathrm{C}-\mathrm{NO}_{2}\right), 140.10(\mathrm{C}-\mathrm{NH}), 138.55(\mathrm{C}-\mathrm{Cl})$, $137.21,135.46,130.80,129.61,129.04,125.15,121.47$, 118.28, 23.57.

\section{2-Chloro-5-[(4-chlorophenyl) sulfamoyl]-N-(2-methyl-3-nitrophenyl)-4-nitrobenzamide (5m)}

\% Yield: 38.29; m.p.: 170-172 ${ }^{\circ} \mathrm{C} ; \mathrm{R}_{\mathrm{f}}: 0.61$ (C:T- 9:1); FTIR (KBr): $v_{\max }\left(\mathrm{cm}^{-1}\right): 3469.45$ (N-H str.), 3095.80 (C-H str., Ar), 2882.55 (C-H str., Aliphatic), 1692.32 $(\mathrm{C}=\mathrm{O}), 1598.62$ ( $\mathrm{N}-\mathrm{H}$ bend), 1530.06 (asym. $\mathrm{NO}_{2}$ str.), 1351.59 (sym. $\mathrm{NO}_{2}$ str.), 1302.76 (asym. $\mathrm{SO}_{2}$ str.), 1177.56 (sym. $\mathrm{SO}_{2}$ str.), 734.45 (C-Cl); ${ }^{1} \mathrm{HNMR}$ (300 MHz, DMSO- $\mathrm{d}_{6}$ ), $\delta$ ppm: 2.14 $\left(\mathrm{s}, \mathrm{H}, \mathrm{CH}_{3}\right.$ of $\left.\mathrm{CONH}-\mathrm{C}_{6} \mathrm{H}_{5} \mathrm{CH}_{3} \mathrm{NO}_{2}-\right)$, $3.37(\mathrm{~s}, 1 \mathrm{H}, \mathrm{NH}), 7.45(\mathrm{~s}, 1 \mathrm{H}$, $\mathrm{CH}$ of $\mathrm{C}_{6}$ of $\mathrm{ClNO}_{2} \mathrm{C}_{6} \mathrm{H}_{2} \mathrm{CONH}-$ ), 7.94-7.95 (d, $2 \mathrm{H}, \mathrm{CH}$ of $\mathrm{C}_{2}$ and $\mathrm{C}_{6}$ of $\left.\mathrm{ClC}_{6} \mathrm{H}_{4} \mathrm{NH}\right), 8.09-8.13\left(\mathrm{~m}, 2 \mathrm{H}, \mathrm{CH} \mathrm{C}_{4}\right.$, $\mathrm{C}_{5}$ andC 6 of $-\mathrm{CONH}-\mathrm{C}_{6} \mathrm{H}_{5} \mathrm{CH}_{3} \mathrm{NO}_{2}-$ ), 8.46-8.47 (d, $2 \mathrm{H}, \mathrm{CH}$ of $\mathrm{C}_{3}$ and $\mathrm{C}_{5}$ of $\left.\mathrm{ClC}_{6} \mathrm{H}_{4} \mathrm{NH}\right), 8.72(\mathrm{~s}, 1 \mathrm{H}, \mathrm{CH}$ of $\mathrm{C}_{3}$ of $\mathrm{ClNO}_{2} \mathrm{C}_{6} \mathrm{H}_{2} \mathrm{CONH}-$ ), $10.50(\mathrm{~s}, 1 \mathrm{H}, \mathrm{NH}) ;{ }^{13} \mathrm{CNMR}$ (300 MHz, DMSO-d ${ }_{6}$ ), $\delta$ ppm: $166.48(\mathrm{C}=\mathrm{O}), 158.10$ (C-S), $146.02\left(\mathrm{C}-\mathrm{NO}_{2}\right), 138.52(\mathrm{C}-\mathrm{NH}), 137.46(\mathrm{C}-\mathrm{Cl})$, $136.78,136.15,131.20,129.89,129.25,128.19,126.71$, 126.26, 117.19, 22.76 .

\section{2-Chloro-N-(2-chloro-4-nitrophenyl)-5-[(4-chlorophenyl) sulfamoyl]-4-nitrobenzamide (5n)}

\% Yield: 79.16; m.p.: 214-216 ${ }^{\circ} \mathrm{C}$; $\mathrm{R}_{\mathrm{f}}$ : 0.34 (B:EA- 7:3); FTIR (KBr): $v_{\max }\left(\mathrm{cm}^{-1}\right): 3461.39(\mathrm{~N}-\mathrm{H}$ str.), 3187.49 (C-H str., Ar), $1626.02(\mathrm{C}=\mathrm{O}), 1587.77$ (asym. $\mathrm{NO}_{2}$ str.), 1378.16 (asym. $\mathrm{SO}_{2}$ str.), 1320.40 (sym. $\mathrm{NO}_{2}$ str.), 1127.06 (sym. $\mathrm{SO}_{2}$ str.), 747.47 (C-Cl); ${ }^{1} \mathrm{HNMR}$ (300 MHz, DMSO-d $\mathrm{d}_{6}$ ), $\delta$ ppm: 3.37 (s, 1H, NH), 7.53 (s, $1 \mathrm{H}, \mathrm{CH}$ of $\mathrm{C}_{6}$ of $\mathrm{ClNO}_{2} \mathrm{C}_{6} \mathrm{H}_{2} \mathrm{CONH}-$ ), 7.80-7.81 (d, $2 \mathrm{H}, \mathrm{CH}$ of $\mathrm{C}_{2}$ and $\mathrm{C}_{6}$ of $\mathrm{ClC}_{6} \mathrm{H}_{4} \mathrm{NH}-$ ), 8.11-8.13 (d, $2 \mathrm{H}$, $\mathrm{CH}$ of $\mathrm{C}_{3}$ and $\mathrm{C}_{5}$ of $\left.\mathrm{NO}_{2} \mathrm{C}_{6} \mathrm{H}_{4} \mathrm{NH}\right), 8.25-8.26(\mathrm{~d}, \mathrm{H}, \mathrm{CH}$ of $\mathrm{C}_{6}$ of $-\mathrm{CONH}-\mathrm{C}_{6} \mathrm{H}_{5} \mathrm{ClNO}_{2}$ ), 8.36-8.38 (d, H, CH of $\mathrm{C}_{5}$ of $\left.-\mathrm{CONH}-\mathrm{C}_{6} \mathrm{H}_{5} \mathrm{ClNO}_{2}\right), 8.51\left(\mathrm{~s}, 1 \mathrm{H}, \mathrm{CH}\right.$ of $\mathrm{C}_{3}$ of $\mathrm{ClNO}_{2} \mathrm{C}_{6} \mathrm{H}_{2} \mathrm{CONH}-$ ), 8.61 (s, H, CH of $\mathrm{C}_{3}$ of $-\mathrm{CONH}-$ $\mathrm{C}_{6} \mathrm{H}_{5} \mathrm{ClNO}_{2}$ ), 10.53 (s, 1H, NH); ${ }^{13} \mathrm{CNMR}(300 \mathrm{MHz}$, DMSO-d $\left.{ }_{6}\right), \delta$ ppm: $168.41(\mathrm{C}=\mathrm{O}), 160.22(\mathrm{C}-\mathrm{S}), 145.06$ $\left(\mathrm{C}-\mathrm{NO}_{2}\right), 138.02(\mathrm{C}-\mathrm{NH}), 136.61(\mathrm{C}-\mathrm{Cl}), 132.42,130.59$, $128.62,128.41,126.57,124.78,122.38,118.76,26.08$.

\section{2-Chloro-5-[(4-chlorophenyl) sulfamoyl]-N-(2-methyl-5-nitrophenyl)-4-nitrobenzamide} (5o)

\% Yield: 93.61; m.p.: $203-205{ }^{\circ} \mathrm{C}$; $\mathrm{R}_{\mathrm{f}}: 0.30$ (B:EA- 7:3); FTIR (KBr): $v_{\max }\left(\mathrm{cm}^{-1}\right): 3488.67(\mathrm{~N}-\mathrm{H}$ str.), 3082.35 (C-H str., Ar), 2979.35, 2899.74 (C-H str., Aliphatic), 1630.01 ( $\mathrm{C}=\mathrm{O}), 1511.16$ (asym. $\mathrm{NO}_{2}$ str.), 1382.02 (asym. $\mathrm{SO}_{2}$ str.), 1345.60 (sym. $\mathrm{NO}_{2}$ str.), 1138.02 (sym. $\mathrm{SO}_{2}$ str.), $737.34 \quad(\mathrm{C}-\mathrm{Cl}) ;{ }^{1} \mathrm{HNMR} \quad(300 \mathrm{MHz}$, DMSO- $\left.\mathrm{d}_{6}\right), \delta$ ppm: $2.14 \quad\left(\mathrm{~s}, \mathrm{H}, \mathrm{CH}_{3}\right.$ of $-\mathrm{CONH}-$ $\mathrm{C}_{6} \mathrm{H}_{5} \mathrm{CH}_{3} \mathrm{NO}_{2}-$ ), 3.37 (s, $\left.1 \mathrm{H}, \mathrm{NH}\right), 7.24-7.29$ (m, $2 \mathrm{H}$, $\mathrm{CH} \mathrm{C}{ }_{3}, \mathrm{C}_{4}$ of $\left.-\mathrm{CONH}-\mathrm{C}_{6} \mathrm{H}_{5} \mathrm{CH}_{3} \mathrm{NO}_{2}-\right), 7.62(\mathrm{~s}, 1 \mathrm{H}$, $\mathrm{CH}$ of $\mathrm{C}_{6}$ of $\left.\mathrm{ClNO}_{2} \mathrm{C}_{6} \mathrm{H}_{2} \mathrm{CONH}-\right)$, 7.84-7.87 (d, $2 \mathrm{H}$, $\mathrm{CH}$ of $\mathrm{C}_{2}$ and $\mathrm{C}_{6}$ of $\left.\mathrm{ClC}_{6} \mathrm{H}_{4} \mathrm{NH}\right), 8.32(\mathrm{~d}, 2 \mathrm{H}, \mathrm{CH}$ of $\mathrm{C}_{3}$ and $\mathrm{C}_{5}$ of $\left.\mathrm{ClC}_{6} \mathrm{H}_{4} \mathrm{NH}\right), 8.41\left(\mathrm{~d}, \mathrm{H}, \mathrm{CH}\right.$ of $\mathrm{C}_{6}$, of $\left.\mathrm{CONH}-\mathrm{C}_{6} \mathrm{H}_{5} \mathrm{CH}_{3} \mathrm{NO}_{2}-\right), 8.29-8.58\left(\mathrm{~s}, 1 \mathrm{H}, \mathrm{CH}\right.$ of $\mathrm{C}_{3}$ of $\left.\mathrm{ClNO}_{2} \mathrm{C}_{6} \mathrm{H}_{2} \mathrm{CONH}-\right), 10.67(\mathrm{~s}, 1 \mathrm{H}, \mathrm{NH}) ;{ }^{13} \mathrm{CNMR}$ (300 MHz, DMSO-d $\left.\mathrm{d}_{6}\right), \delta \mathrm{ppm}: 163.88(\mathrm{C}=\mathrm{O}), 153.37$ (C-S), 147.61(C-NO $\left.)_{2}\right), 139.52(\mathrm{C}-\mathrm{NH}), 137.36(\mathrm{C}-\mathrm{Cl})$, $130.91,129.21,128.35,127.24,124.82,122.63,118.04$, $110.49,18.53$.

\section{2-Chloro-5-[(4-chlorophenyl) sulfamoyl]-N-(2-methyl-4-nitrophenyl)-4-nitrobenzamide} (5p)

\% Yield: 56.66; m.p.: $104-106{ }^{\circ} \mathrm{C}$; $\mathrm{R}_{\mathrm{f}}: 0.50$ (B:EA- 7:3); FTIR (KBr): $v_{\max }\left(\mathrm{cm}^{-1}\right): 3473.73$ (N-H str.), 3090.98 (C-H str., Ar), 2838.62 (C-H str., Aliphatic), 1640.49 $(\mathrm{C}=\mathrm{O}), 1586.11$ ( $\mathrm{N}-\mathrm{H}$ bend), 1529.58 (asym. $\mathrm{NO}_{2}$ str.), 1396.49 (asym. $\mathrm{SO}_{2}$ str.), 1350.19 (sym. $\mathrm{NO}_{2}$ str.), 1154.21 (sym. $\mathrm{SO}_{2}$ str.), 740.69 (C-Cl); ${ }^{1} \mathrm{HNMR}$ (300 MHz, DMSO-d $\mathrm{d}_{6}$ ), $\delta$ ppm: $2.12\left(\mathrm{~s}, \mathrm{H}, \mathrm{CH}_{3}\right.$ of $\left.\mathrm{CONH}-\mathrm{C}_{6} \mathrm{H}_{5} \mathrm{CH}_{3} \mathrm{NO}_{2}-\right), 3.46(\mathrm{~s}, 1 \mathrm{H}, \mathrm{NH}), 7.51$ (s, H, $\mathrm{CH}$ of $\mathrm{C}_{3}$ of $\left.-\mathrm{CONH}-\mathrm{C}_{6} \mathrm{H}_{5} \mathrm{CH}_{3} \mathrm{NO}_{2}-\right), 7.67(\mathrm{~s}, 1 \mathrm{H}, \mathrm{CH}$ of $\mathrm{C}_{6}$ of $\left.\mathrm{ClNO}_{2} \mathrm{C}_{6} \mathrm{H}_{2} \mathrm{CONH}-\right), 7.84-7.87(\mathrm{~d}, 2 \mathrm{H}, \mathrm{CH}$ of $\mathrm{C}_{2}$ and $\mathrm{C}_{6}$ of $\mathrm{ClC}_{6} \mathrm{H}_{4} \mathrm{NH}-$ ), 8.21-8.25 (m, $2 \mathrm{H}, \mathrm{CH}$ $\mathrm{C}_{5}, \mathrm{C}_{6}$ of $-\mathrm{CONH}-\mathrm{C}_{6} \mathrm{H}_{5} \mathrm{CH}_{3} \mathrm{NO}_{2}-$ ), 8.47-8.48 (d, $2 \mathrm{H}$, $\mathrm{CH}$ of $\mathrm{C}_{3}$ and $\mathrm{C}_{5}$ of $\left.\mathrm{ClC}_{6} \mathrm{H}_{4} \mathrm{NH}-\right), 8.64\left(\mathrm{~s}, 1 \mathrm{H}, \mathrm{CH}\right.$ of $\mathrm{C}_{3}$ of $\left.\mathrm{ClNO}_{2} \mathrm{C}_{6} \mathrm{H}_{2} \mathrm{CONH}-\right), 10.70(\mathrm{~s}, 1 \mathrm{H}, \mathrm{NH}) ;{ }^{13} \mathrm{CNMR}$ (300 MHz, DMSO- $\left.\mathrm{d}_{6}\right), \delta$ ppm: $167.72(\mathrm{C}=\mathrm{O}), 154.62$ (C-S), $148.40\left(\mathrm{C}-\mathrm{NO}_{2}\right), 141.67(\mathrm{C}-\mathrm{NH}), 135.94(\mathrm{C}-\mathrm{Cl})$, $130.20,128.44,126.61,124.87,124.39,120.86,112.81$, 17.59 . 


\section{2-Chloro-N-(4-chlorophenyl)-5-[(4-chlorophenyl)} sulfamoyl]-4-nitrobenzamide (5q)

\% Yield: 95.24; m.p.: 177-179 ${ }^{\circ} \mathrm{C}$; $\mathrm{R}_{\mathrm{f}}$ : 0.65 (B:EA7:3); FTIR (KBr): $v_{\max }\left(\mathrm{cm}^{-1}\right): 3483.02(\mathrm{~N}-\mathrm{H}$ str.), $3108.34(\mathrm{C}-\mathrm{H}$ str., Ar), $1633.74(\mathrm{C}=\mathrm{O}), 1599.82(\mathrm{~N}-\mathrm{H}$ bend), 1530.54 (asym. $\mathrm{NO}_{2}$ str.), 1396.49 (asym. $\mathrm{SO}_{2}$ str.), 1353.09 (sym. $\mathrm{NO}_{2}$ str.), 1183.49 (sym. $\mathrm{SO}_{2}$ str.), $754.34(\mathrm{C}-\mathrm{Cl}){ }^{1} \mathrm{HNMR}$ (300 MHz, DMSO-d $\left.{ }_{6}\right)$, $\delta$ ppm: $3.67(\mathrm{~s}, 1 \mathrm{H}, \mathrm{NH}), 7.44-7.46\left(\mathrm{~d}, 2 \mathrm{H}, \mathrm{CH}\right.$ of $\mathrm{C}_{2}$ and $\mathrm{C}_{6}$ of $\left.-\mathrm{ClC}_{6} \mathrm{H}_{4} \mathrm{NH}-\right), 7.60\left(\mathrm{~s}, 1 \mathrm{H}, \mathrm{CH}\right.$ of $\mathrm{C}_{6}$ of $\mathrm{ClNO}_{2} \mathrm{C}_{6} \mathrm{H}_{2} \mathrm{CONH}-$ ), 7.95-7.96 (d, 2H, CH of $\mathrm{C}_{2}$ and $\mathrm{C}_{6}$ of $\left.-\mathrm{CONHC}_{6} \mathrm{H}_{5} \mathrm{Cl}-\right)$, 8.00-8.02 (d, $2 \mathrm{H}, \mathrm{CH}$ of $\mathrm{C}_{3}$ and $\mathrm{C}_{5}$ of $\left.-\mathrm{CONH}-\mathrm{C}_{6} \mathrm{H}_{5} \mathrm{Cl}-\right), 8.24-8.26(\mathrm{~d}, 2 \mathrm{H}, \mathrm{CH}$ of $\mathrm{C}_{3}$ and $\mathrm{C}_{5}$ of $\left.-\mathrm{ClC}_{6} \mathrm{H}_{4} \mathrm{NH}-\right), 8.36\left(\mathrm{~s}, 1 \mathrm{H}, \mathrm{CH}\right.$ of $\mathrm{C}_{3}$ of $\left.\mathrm{ClNO}_{2} \mathrm{C}_{6} \mathrm{H}_{2} \mathrm{CONH}-\right), 10.63(\mathrm{~s}, 1 \mathrm{H}, \mathrm{NH}) ;{ }^{13} \mathrm{CNMR}$ (300 MHz, DMSO-d $\left.{ }_{6}\right), \delta$ ppm: $166.17(\mathrm{C}=\mathrm{O}), 156.21$ $(\mathrm{C}-\mathrm{S}), 149.28\left(\mathrm{C}-\mathrm{NO}_{2}\right), 138.40(\mathrm{C}-\mathrm{NH}), 138.06(\mathrm{C}-\mathrm{Cl})$, $136.11,131.94,132.52,129.89,126.84,125.71,123.20$, 112.90 .

\section{2-Chloro-5-[(4-chlorophenyl) sulfamoyl]-4-nitro- $\mathrm{N}$-(3-nitrophenyl)benzamide (5r)}

\% Yield: 84.37; m.p.: $135-137{ }^{\circ} \mathrm{C}$; $\mathrm{R}_{\mathrm{f}}$ 0.59 (B:EA- 7:3); FTIR $(\mathrm{KBr}): v_{\max }\left(\mathrm{cm}^{-1}\right): 3294.47(\mathrm{~N}-\mathrm{H}$ str.), $3102.55(\mathrm{C}-\mathrm{H}$ str., Ar), $1618.98(\mathrm{C}=\mathrm{O}), 1569.12(\mathrm{~N}-\mathrm{H}$ bend $), 1549.18$ (asym. $\mathrm{NO}_{2}$ str.), 1398.42 (asym. $\mathrm{SO}_{2}$ str.), 1353.37 (sym. $\mathrm{NO}_{2}$ str.), 1133.20 (sym. $\mathrm{SO}_{2}$ str.), 732.87 (C-Cl); ${ }^{1} \mathrm{HNMR}$ $\left(300 \mathrm{MHz}, \mathrm{DMSO}-\mathrm{d}_{6}\right), \delta \mathrm{ppm}: 4.08(\mathrm{~s}, 1 \mathrm{H}, \mathrm{NH}), 7.05$ (s, $1 \mathrm{H}, \mathrm{CH}$ of $\mathrm{C}_{6}$ of $\mathrm{ClNO}_{2} \mathrm{C}_{6} \mathrm{H}_{2} \mathrm{CONH}-$ ), 7.34-7.49 (t, $1 \mathrm{H}, \mathrm{CH}$ of $\mathrm{C}_{5}$ of $\left.-\mathrm{CONH}-\mathrm{C}_{6} \mathrm{H}_{5} \mathrm{NO}_{2}-\right)$, 7.91-7.93 (d, $2 \mathrm{H}, \mathrm{CH}$ of $\mathrm{C}_{2}$ and $\mathrm{C}_{6}$ of $\left.\mathrm{ClC}_{6} \mathrm{H}_{4} \mathrm{NH}\right), 8.00-8.02(\mathrm{~d}, 1 \mathrm{H}$, $\mathrm{CH}$ of $\mathrm{C}_{6}$ of $\left.-\mathrm{CONH}-\mathrm{C}_{6} \mathrm{H}_{5} \mathrm{NO}_{2}-\right)$, 8.24-8.26 (d, $2 \mathrm{H}$, $\mathrm{CH}$ of $\mathrm{C}_{3}$ and $\mathrm{C}_{5}$ of $\left.\mathrm{ClC}_{6} \mathrm{H}_{4} \mathrm{NH}\right), 8.36-8.39(\mathrm{~d}, 1 \mathrm{H}, \mathrm{CH}$ of $\mathrm{C}_{4}$ of $\left.-\mathrm{CONH}-\mathrm{C}_{6} \mathrm{H}_{5} \mathrm{NO}_{2}-\right), 8.64\left(\mathrm{~s}, 1 \mathrm{H}, \mathrm{CH}\right.$ of $\mathrm{C}_{3}$ of $\mathrm{ClNO}_{2} \mathrm{C}_{6} \mathrm{H}_{2} \mathrm{CONH}-$ ), 8.95 (s, $1 \mathrm{H}, \mathrm{CH}$ of $\mathrm{C}_{2}$ of $-\mathrm{CONH}-$ $\left.\mathrm{C}_{6} \mathrm{H}_{5} \mathrm{NO}_{2}-\right), 10.81$ (s, $\left.1 \mathrm{H}, \mathrm{NH}\right) ;{ }^{13} \mathrm{CNMR}(300 \mathrm{MHz}$, DMSO-d $\left.{ }_{6}\right), \delta$ ppm: $165.98(\mathrm{C}=\mathrm{O}), 161.31(\mathrm{C}-\mathrm{S}), 149.25$ $\left(\mathrm{C}-\mathrm{NO}_{2}\right), 139.61(\mathrm{C}-\mathrm{NH}), 132.26(\mathrm{C}-\mathrm{Cl}), 130.24,125.93$, 124.56, 123.59, 118.85, 113.87 .

\section{2-Chloro-5-[(4-chlorophenyl) \\ sulfamoyl]-4-nitro-N-propylbenzamide (5s)}

\% Yield: 57.89; m.p.: $116-118{ }^{\circ} \mathrm{C}$; $\mathrm{R}_{\mathrm{f}}$ : 0.66 (Chloroform); FTIR (KBr): $v_{\max }\left(\mathrm{cm}^{-1}\right): 3524.01$ (N-H str.), 3089.05 (C-H str., Ar), 2967.82, 2874.42 (C-H str., Aliphatic), $1650.13(\mathrm{C}=\mathrm{O}), 1598.78$ ( $\mathrm{N}-\mathrm{H}$ bend), 1533.43 (asym. $\mathrm{NO}_{2}$ str.), 1372.38 (sym. $\mathrm{SO}_{2}$ str.), 1309.34 (sym. $\mathrm{NO}_{2}$ str.), 1168.88 (sym. $\mathrm{SO}_{2}$ str.), 755.90 (CCl). ${ }^{1} \mathrm{HNMR}\left(300 \mathrm{MHz}, \mathrm{DMSO}-\mathrm{d}_{6}\right.$ ), $\delta \mathrm{ppm}: 1.82-1.90$ $\left(\mathrm{m}, 7 \mathrm{H},-\mathrm{CONH}-\mathrm{C}_{3} \mathrm{H}_{7}\right), 3.39(\mathrm{~s}, 1 \mathrm{H}, \mathrm{NH}), 7.50(\mathrm{~s}$, $1 \mathrm{H}, \mathrm{CH}$ of $\mathrm{C}_{6}$ of $\mathrm{ClNO}_{2} \mathrm{C}_{6} \mathrm{H}_{2} \mathrm{CONH}-$ ), 7.80-7.83 (d, $2 \mathrm{H}, \mathrm{CH}$ of $\mathrm{C}_{2}$ and $\mathrm{C}_{6}$ of $\left.\mathrm{ClC}_{6} \mathrm{H}_{4} \mathrm{NH}\right), 8.21-8.23(\mathrm{~d}, 2 \mathrm{H}$, $\mathrm{CH}$ of $\mathrm{C}_{3}$ and $\mathrm{C}_{5}$ of $\left.\mathrm{ClC}_{6} \mathrm{H}_{4} \mathrm{NH}\right), 8.51\left(\mathrm{~s}, 1 \mathrm{H}, \mathrm{CH}\right.$ of $\mathrm{C}_{3}$ of $\left.\mathrm{ClNO}_{2} \mathrm{C}_{6} \mathrm{H}_{2} \mathrm{CONH}-\right), 10.32(\mathrm{~s}, 1 \mathrm{H}, \mathrm{NH}) ;{ }^{13} \mathrm{CNMR}$ (300 MHz, DMSO- $\left.\mathrm{d}_{6}\right), \delta$ ppm: $162.67(\mathrm{C}=\mathrm{O}), 158.75$ (C-S), $146.08\left(\mathrm{C}-\mathrm{NO}_{2}\right), 139.51(\mathrm{C}-\mathrm{NH}), 135.49(\mathrm{C}-\mathrm{Cl})$, 132.72, 128.73, 128.06, 126.60, 31.15, 26.04, 21.41.

\section{N-Butyl-2-chloro-5-[(4-chlorophenyl) sulfamoyl]-4-nitrobenzamide (5t)}

\% Yield: 84.54 ; m.p.: $111-113{ }^{\circ} \mathrm{C}$; $\mathrm{R}_{\mathrm{f}}$ : 0.54 (Chloroform); FTIR (KBr): $v_{\max }\left(\mathrm{cm}^{-1}\right): 3446.85$ (N-H str.), 3186.46 (C-H str., Ar), 2959.53, 2871.74 (C-H str., Aliphatic), $1658.64(\mathrm{C}=\mathrm{O}), 1597.82(\mathrm{~N}-\mathrm{H}$ bend $), 1531.51$ (asym. $\mathrm{NO}_{2}$ str.), 1372.38 (asym. $\mathrm{SO}_{2}$ str.), 1309.80 (sym. $\mathrm{NO}_{2}$ str.), 1174.67 (sym. $\mathrm{SO}_{2}$ str.), 750.37 (C$\mathrm{Cl}) ;{ }^{1} \mathrm{HNMR}\left(300 \mathrm{MHz}, \mathrm{DMSO}-\mathrm{d}_{6}\right.$ ), $\delta$ ppm: $2.08-2.18$ $\left(\mathrm{m}, 9 \mathrm{H},-\mathrm{CONH}-\mathrm{C}_{4} \mathrm{H}_{9}\right), 3.71(\mathrm{~s}, 1 \mathrm{H}, \mathrm{NH}), 7.46(\mathrm{~s}, 1 \mathrm{H}$, $\mathrm{CH}$ of $\mathrm{C}_{6}$ of $\mathrm{ClNO}_{2} \mathrm{C}_{6} \mathrm{H}_{2} \mathrm{CONH}-$ ), 7.79-7.80 (d, $2 \mathrm{H}$, $\mathrm{CH}$ of $\mathrm{C}_{2}$ and $\mathrm{C}_{6}$ of $\left.\mathrm{ClC}_{6} \mathrm{H}_{4} \mathrm{NH}\right), 8.22-8.24(\mathrm{~d}, 2 \mathrm{H}, \mathrm{CH}$ of $\mathrm{C}_{3}$ and $\mathrm{C}_{5}$ of $\left.\mathrm{NO}_{2} \mathrm{C}_{6} \mathrm{H}_{4} \mathrm{NH}\right), 8.50\left(\mathrm{~s}, 1 \mathrm{H}, \mathrm{CH}\right.$ of $\mathrm{C}_{3}$ of $\left.\mathrm{ClNO}_{2} \mathrm{C}_{6} \mathrm{H}_{2} \mathrm{CONH}-\right), 10.51(\mathrm{~s}, 1 \mathrm{H}, \mathrm{NH}) ;{ }^{13} \mathrm{CNMR}$ (300 MHz, DMSO-d $\left.\mathrm{d}_{6}\right), \delta \mathrm{ppm}: 160.69(\mathrm{C}=\mathrm{O}), 155.52$ $(\mathrm{C}-\mathrm{S}), 144.08\left(\mathrm{C}-\mathrm{NO}_{2}\right), 138.84(\mathrm{C}-\mathrm{NH}), 136.60(\mathrm{C}-\mathrm{Cl})$, 133.53, 129.57, 128.48, 127.57, 32.15, 27.34, 18.99.

\section{2-Chloro-5-[(4-chlorophenyl)sulfamoyl]-N-[(furan-2-yl) methyl]-4-nitrobenzamide (5u)}

\% Yield: 67.48; m.p.: $191-193{ }^{\circ} \mathrm{C}$; $\mathrm{R}_{\mathrm{f}}$ : 0.40 (B:EA- 7:3); FTIR (KBr): $v_{\max }\left(\mathrm{cm}^{-1}\right): 3503.75$ (N-H str.), 3056.03 (C-H str., Ar), 2981.34 (C-H str., Aliphatic), 1665.16 $(\mathrm{C}=\mathrm{O}), 1596.15$ ( $\mathrm{N}-\mathrm{H}$ bend), 1506.43 (asym. $\mathrm{NO}_{2}$ str.), 1396.80 (asym. $\mathrm{SO}_{2}$ str.), 1376.23 (sym. $\mathrm{NO}_{2}$ str.), 1149.59 (sym. $\mathrm{SO}_{2}$ str.), 743.60 (C-Cl); ${ }^{1} \mathrm{HNMR}$ (300 MHz, DMSO-d $\left.)_{6}\right), \delta: 2.59$ (s, $2 \mathrm{H}, \mathrm{CH}$ of $\mathrm{CONH}-$ $\left.\mathrm{CH}_{2}-\mathrm{C}_{4} \mathrm{H}_{3} \mathrm{O}\right), 3.71(\mathrm{~s}, 1 \mathrm{H}, \mathrm{NH}), 7.61(\mathrm{~s}, 1 \mathrm{H}, \mathrm{CH}$ of $\mathrm{C}_{6}$ of $\mathrm{ClNO}_{2} \mathrm{C}_{6} \mathrm{H}_{2} \mathrm{CONH}-$ ), 7.79-7.87 (m, 3H, CH of $\mathrm{C}_{2}, \mathrm{C}_{3}$ and $\mathrm{C} 4$ of $\mathrm{CONH}-\mathrm{CH}_{2}-\mathrm{C}_{4} \mathrm{H}_{3} \mathrm{O}$ ), 7.92-7.93 (d, $2 \mathrm{H}, \mathrm{CH}$ of $\mathrm{C}_{2}$ and $\mathrm{C}_{6}$ of $\left.\mathrm{ClC}_{6} \mathrm{H}_{4} \mathrm{NH}\right), 8.22-8.24(\mathrm{~d}, 2 \mathrm{H}$, $\mathrm{CH}$ of $\mathrm{C}_{3}$ and $\mathrm{C}_{5}$ of $\left.\mathrm{ClC}_{6} \mathrm{H}_{4} \mathrm{NH}\right), 8.50\left(\mathrm{~s}, 1 \mathrm{H}, \mathrm{CH}\right.$ of $\mathrm{C}_{3}$ of $\left.\mathrm{ClNO}_{2} \mathrm{C}_{6} \mathrm{H}_{2} \mathrm{CONH}-\right), 10.58(\mathrm{~s}, 1 \mathrm{H}, \mathrm{NH}) ;{ }^{13} \mathrm{CNMR}$ (300 MHz, DMSO- $\left.\mathrm{d}_{6}\right), \delta$ ppm: $165.97(\mathrm{C}=\mathrm{O}), 157.03$ $(\mathrm{C}-\mathrm{S}), 145.82\left(\mathrm{C}-\mathrm{NO}_{2}\right), 142.54(\mathrm{C}-\mathrm{NH}), 136.72(\mathrm{C}-\mathrm{Cl})$, $130.46,129.18,125.49,121.85,120.80,113.64,32.59$.

\section{2-Chloro-5-[(4-chlorophenyl)}

\section{sulfamoyl]-4-nitro-N-(pyridin-4-yl)benzamide (5v)}

\% Yield: 71.32; m.p.: $197-199^{\circ} \mathrm{C}$; $\mathrm{R}_{\mathrm{f}}$ : 0.31 (B:EA- 7:3); FTIR $(\mathrm{KBr}): v_{\max }\left(\mathrm{cm}^{-1}\right): 3503.75(\mathrm{~N}-\mathrm{H}$ str.), $3113.16(\mathrm{C}-\mathrm{H}$ str., Ar), $1665.56(\mathrm{C}=\mathrm{O}), 1598.05(\mathrm{~N}-\mathrm{H}$ bend $), 1548.50$ (asym. $\mathrm{NO}_{2}$ str.), 1371.07 (asym. $\mathrm{SO}_{2}$ str.), 1316.44 (sym. $\mathrm{NO}_{2}$ str.), 1170.81 (sym. $\mathrm{SO}_{2}$ str.), $755.14(\mathrm{C}-\mathrm{Cl}) ;{ }^{1} \mathrm{HNMR}$ (300 MHz, DMSO-d $\mathrm{d}_{6}$ ), $\delta$ ppm: $3.71(\mathrm{~s}, 1 \mathrm{H}, \mathrm{NH}), 7.57(\mathrm{~s}$, $1 \mathrm{H}, \mathrm{CH}$ of $\mathrm{C}_{6}$ of $\left.\mathrm{ClNO}_{2} \mathrm{C}_{6} \mathrm{H}_{2} \mathrm{CONH}-\right), 7.80-7.83(\mathrm{~d}, 2 \mathrm{H}$, $\mathrm{CH}$ of $\mathrm{C}_{2}$ and $\mathrm{C}_{6}$ of $\left.\mathrm{ClC}_{6} \mathrm{H}_{4} \mathrm{NH}-\right)$, 7.93-7.96 (d, $2 \mathrm{H}, \mathrm{CH}$ of $\mathrm{C}_{2}$ and $\mathrm{C}_{6}$ of $\left.-\mathrm{CONH}-\mathrm{C}_{5} \mathrm{H}_{4} \mathrm{NH}-\right)$, 8.24-8.26 (d, $2 \mathrm{H}$, 
$\mathrm{CH}$ of $\mathrm{C}_{3}$ and $\mathrm{C}_{5}$ of $\left.\mathrm{ClC}_{6} \mathrm{H}_{4} \mathrm{NH}-\right)$, 8.36-8.39 (d, $2 \mathrm{H}, \mathrm{C}_{3}$ and $\mathrm{C}_{5} \mathrm{CH}$ of $\left.-\mathrm{CONH}-\mathrm{C}_{5} \mathrm{H}_{4} \mathrm{NH}\right), 8.50(\mathrm{~s}, 1 \mathrm{H}, \mathrm{CH}$ of $\mathrm{C}_{3}$ of $\left.\mathrm{ClNO}_{2} \mathrm{C}_{6} \mathrm{H}_{2} \mathrm{CONH}-\right), 10.56(\mathrm{~s}, 1 \mathrm{H}, \mathrm{NH}) ;{ }^{13} \mathrm{CNMR}$ (300 MHz, DMSO-d $\left.)_{6}\right), \delta$ ppm: $164.70(\mathrm{C}=\mathrm{O}), 156.22$ $(\mathrm{C}-\mathrm{S}), 148.17\left(\mathrm{C}-\mathrm{NO}_{2}\right), 144.89(\mathrm{C}-\mathrm{NH}), 138.96(\mathrm{C}-\mathrm{Cl})$, 130.34, 128.50, 125.55, 120.17 .

\section{In vitro antidiabetic studies a-Glucosidase inhibitory assay}

The method adopted for performing $\alpha$-glucosidase inhibitory assay was similar to our prevenient study, Thakral and Singh [32]. Graph Pad Prism program, version 5 was employed for calculation of the $50 \%$ inhibitory concentration $\left(\mathrm{IC}_{50}\right)$ of all compound $[32,42,43]$.

\section{a-Amylase inhibitory assay}

Xiao et al., and Yoshikawa et al., illustrated a method, with little modification this method has been adopted for measuring the activity [32, 44].

\section{Homology modeling}

The 3D model for $\alpha$-glucosidase is developed by comparative homology modeling technique using SWISSMODEL web server (https://swissmodel.expasy.org/) [45] and then the quality of modeled structure was validated by Ramachandran plot (RAMPAGE) (http://mordr ed.bioc.cam.ac.uk/ rapper/rampage.php). The details are available in our previous report [32].

\section{Molecular docking}

Ligand molecules were prepared as per reported method [32] using MarvinSketch and AutoDock tools. The crystal structures of $\alpha$-amylase, 1qho [32, 46] from Bacillus sterothermophilus, maltose/acarbose complex downloaded from the protein data bank (http://www.rcsb.org) and $\alpha$-glucosidase modeled structure [32] was used for docking in antidiabetic evaluation. Docking studies were carried out as reported in our previous study and literature using AutoDock Vina program [32, 47].

\section{Molecular dynamic simulations}

The respective structures placed in the center of the cubic box, the remaining volume of the box was filled by SPCe [48] water molecules. The whole box is then neutralized by adding the respective number of positive and negative ions using GROMACS 5.4 [49] by replacing the equal number of water molecules. Further energy minimization followed by $10 \mathrm{~ns}$ equilibration performed by using OPLS [50] force fields integrated into GROMACS 5.4 package to represent the potential energy of the system.

\section{Computation of drug like parameters and ADMET profiling} Molinspiration (http://www.molinspiration.com/) online tool kit and OSIRIS property explorer was used for computing drug like characteristics from $2 \mathrm{D}$ chemical structures of aforementioned compounds [51-54]. Pre-ADMET online server (https://preadmet.bmdrc .kr/) was used for calculating pharmacokinetic parameters like adsorption, distribution, metabolism and excretion and some of the computed properties are human intestinal absorption (HIA \%), Caco-2 cell permeability (nm/s), MDCK (Medin-Darbey Canine Kidney Epithelial Cells) cell permeability $(\mathrm{nm} / \mathrm{s})$, plasma protein binding (\%), blood brain barrier penetration (C. brain/C. blood) and Pgp inhibition [55]. Bioactivity of synthesized compounds was predicted by Molinspiration (http://www.molinspiration.com/) online tool kit [56] and toxicity parameters like mutagenicity, tumorigenicity irritating effects and reproductive effects were computed by OSIRIS property explorer [57].

\section{Supplementary information}

Supplementary information accompanies this paper at https://doi. org/10.1186/s13065-020-00703-4.

Additional file 1: Table S1. Topological polar surface area, aqueous solubility, number of rotatable bonds, and calculated Lipinski's rule of five for the synthesized 2-chloro-5-[(4-chlorophenyl)sulfamoyl]-N-(alkyl/aryl)-4-nitrobenzamide derivatives; Table S2. ADME property values of synthesized 2-chloro-5-[(4-chlorophenyl) sulfamoyl]- $N$-(alkyl/aryl)-4-nitrobenzamide derivatives using Pre-ADMET online server; Table S3. Bioactivity and toxicity risk of synthesized 2-chloro-5-[(4-chlorophenyl)sulfa-moyl]- $\mathrm{N}$-(alkyl/ aryl)-4-nitrobenzamide derivatives

\section{Acknowledgements}

The authors are thankful to Chairman, Department of Pharmaceutical Sciences, G. J. U. S. and T., Hisar for providing necessary facilities to carry out this research work and Prof. Neeraj Dilbaghi, Dept of Bio \&Nano Technology, G. J. U. S. and T., Hisar for providing lab facility for in vitro studies. The authors are also thankful to Amit Singh, Discipline of Chemistry, Indian Institute of Technology, Gandhinagar for facilitation in computational studies.

\section{Authors' contributions}

The authors (ST, RN, MK and VS) have done synthetic work, in vitro and in silico evaluation. All authors have read and approved the manuscript.

\section{Funding}

The author (VS) gratefully acknowledges the financial support (CIL/2017/356) as minor project for purchase of chemicals and Junior Research Fellow (JRF) award to Ms. Samridhi Thakral by Dr. A. P. J. Abdul Kalam Central Instrumentation laboratory, G. J. U. S. and T., Hisar under DST-PURSE program.

\section{Availability of data and materials}

Not applicable.

\section{Competing interests}

The authors declare that they have no competing interests.

\section{Author details}

${ }^{1}$ Department of Pharmaceutical Sciences, Guru Jambheshwar University of Science and Technology, Hisar 125001, India. ${ }^{2}$ Institute of Pharmaceutical Sciences, Kurukshetra University, Kurukshetra 136118, Haryana, India. 
Received: 27 February 2020 Accepted: 3 August 2020

Published online: 09 August 2020

\section{References}

1. Kar K, Krithika U, Mithuna BP, Kumar SS, Reji A, Kumar BRP (2014) Design, synthesis and glucose uptake activity of some novel glitazones. Bioorg Chem 56:27-33

2. Li K, Yao F, Xue Q, Fan H, Yang L, Li X, Sun L, Liu Y (2015) Inhibitory effects against $\mathrm{a}$-glucosidase and a-amylase of the flavonoids-rich extract from Scutellaria baicalensis shoots and interpretation of structure-activity relationship of its eight flavonoids by a refined assign-score method. Chem Cent J 12(1):82

3. Chinthala $Y$, Thakur S, Tirunagari S, Chinde S, Kumar A, Domatti AK, Arigari NK, Srinivas KVNS, Alam S, Jonalla K, Khan F, Tiwari A, Grover P (2015) Synthesis, docking and ADMET studies of novel chalcone triazoles for anti-cancer and anti-diabetic activity. Eur J Med Chem 93:564-573

4. Kim KY, Nguyen TH, Kurihara H, Kim SM (2010) a-Glucosidase inhibitory activity of bromophenol purified from the red alga Polyopes lancifolia. J Food Sci 75(5):145-150

5. Wang G, Li X, Wang J, Xie Z, Li L, Chen M, Chen S, Peng Y (2017) Synthesis, molecular docking and a-glucosidase inhibition of 2-((5, 6-diphenyl-1, 2, 4-triazin-3-yl) thio)-N-arylacetamides. Bioorg Med Chem Lett 27(5):1115-1118

6. Lopéz D, Cherigo L, Mejia LC, Loza-Mejía MA, Martínez-Luis S (2019) a-Glucosidase inhibitors from a mangrove associated fungus, Zasmidium sp. strain EM5-10. BMC Chem 13(1):22

7. Abuelizz HA, Iwana NA, Ahmad R, Anouar EH, Marzouk M, Al-Salahi R (2019) Synthesis, biological activity and molecular docking of new tricyclic series as a-glucosidase inhibitors. BMC Chem 13(1):52

8. Barakat A, Ali M, Al-Majid AM, Yousuf S, Choudhary MI, Khalil R, UI-Haq Z (2017) Synthesis of thiobarbituric acid derivatives: in vitro a-glucosidase inhibition and molecular docking studies. Bioorg Chem 75:99-105

9. Gollapalli M, Taha M, Javid MT, Almandil NB, Rahim F, Wadood A, Mosaddik A, Ibrahim M, Alqahtani MA, Bamarouf YA (2019) Synthesis of benzothiazole derivatives as a potent a-glucosidase inhibitor. Bioorg Chem 85:33-48

10. Imran S, Taha M, Ismail NH, Kashif SM, Rahim F, Jamil W, Hariono M, Yusuf M, Wahab H (2015) Synthesis of novel flavone hydrazones: in vitro evaluation of a-glucosidase inhibition, QSAR analysis and docking studies. Eur J Med Chem 105:156-170

11. El-Karim SSA, Anwar MM, Syam YM, Nael MA, Ali HF, Motaleb MA (2018) Rational design and synthesis of new tetralin-sulfonamide derivatives as potent anti-diabetics and DPP-4 inhibitors: 2D \& 3D QSAR, in vivo radiolabeling and bio distribution studies. Bioorg Chem 81:481-493

12. Naaz F, Srivastava R, Singh A, Singh N, Verma R, Singh VK, Singh RK (2018) Molecular modeling, synthesis, antibacterial and cytotoxicity evaluation of sulfonamide derivatives of benzimidazole, indazole, benzothiazole and thiazole. Bioorgan Med Chem 26(12):3414-3428

13. Krishnaiah M, de Almeida NR, Udumula V, Song Z, Chhonker YS, Abdelmoaty MM, do Nascimento VA, Murry DJ, Conda-Sheridan M (2018) Synthesis, biological evaluation, and metabolic stability of phenazine derivatives as antibacterial agents. Eur J Med Chem 143:936-947

14. Ahmed A, Channar PA, Saeed A, Kalesse M, Kazi MA, Larik FA, Abbas Q, Hassan M, Raza H, Seo SY (2019) Synthesis of sulfonamide, amide and amine hybrid pharmacophore, an entry of new class of carbonic anhydrase II inhibitors and evaluation of chemo-informatics and binding analysis. Bioorg Chem 86:624-630

15. Navarrete-Vázquez G, Morales-Vilchis MG, Estrada-Soto S, RamírezEspinosa JJ, Hidalgo-Figueroa S, Nava-Zuazo C, Tlahuext H, Leon-Rivera I, Medina-Franco JL, López-Vallejo F, Webster SP (2014) Synthesis of 2-\{2-[(a/ $\beta$-naphthalen-1-ylsulfonyl) amino]-1, 3-thiazol-4-yl\} acetamides with $11 \beta$-hydroxysteroid dehydrogenase inhibition and in combo antidiabetic activities. Eur J Med Chem 74:179-186

16. Ghareb N, El-Sayed NM, Abdelhameed R, Yamada K, Elgawish MS (2019) Toward a treatment of diabesity: rational design, synthesis and biological evaluation of benzene-sulfonamide derivatives as a new class of PTP-1B inhibitors. Bioorg Chem 86:322-338
17. Durgapal SD, Soman SS (2019) Evaluation of novel coumarin-proline sulfonamide hybrids as anticancer and antidiabetic agents. Synth Commun. https://doi.org/10.1080/00397911.2019.1647439

18. Singh V, Pacitto A, Donini S, Ferraris DM, Boros S, Illyés E, Szokol B, Rizzi M, Blundell TL, Ascher DB, Pato J (2019) Synthesis and structure-activity relationship of 1-(5-isoquinolinesulfonyl) piperazine analogues as inhibitors of Mycobacterium tuberculosis IMPDH. Eur J Med Chem 174:309-329

19. Ugwu DI, Okoro UC, Ahmad H (2017) New carboxamide derivatives bearing benzenesulphonamide as a selective COX-II inhibitor: design, synthesis and structure-activity relationship. PLoS ONE 12(9):e0183807

20. Banuppriya G, Sribalan R, Padmini V (2018) Synthesis and characterization of curcumin-sulfonamide hybrids: biological evaluation and molecular docking studies. J Mol Struct 1155:90-100

21. Ji Y, Chen X, Chen H, Zhang X, Fan Z, Xie L, Ma B, Zhu C (2019) Designing of acyl sulphonamide based quinoxalinones as multifunctional aldose reductase inhibitors. Bioorg Med Chem 27(8):1658-1669

22. Abbas A, Murtaza S, Tahir MN, Shamim S, Sirajuddin M, Rana UA, Naseem K, Rafique H (2016) Synthesis, antioxidant, enzyme inhibition and DNA binding studies of novel $\mathrm{N}$-benzylated derivatives of sulfonamide. J Mol Struct 1117(5):269-275

23. Gatadi S, Gour J, Shukla M, Kaul G, Dasgupta A, Madhavi YV, Chopra S, Nanduri S (2019) Synthesis and evaluation of new 4-oxoquinazolin-3 $(4 \mathrm{H})-\mathrm{yl})$ benzoic acid and benzamide derivatives as potent antibacterial agents effective against multidrug resistant Staphylococcus aureus. Bioorg Chem 83:569-579

24. Dev J, Poornachandra Y, Kumar N, Ravikumar N, Ranjithreddy P, Kumar S, Nanubolu JB, Kumar G, Narsaiah B (2017) Synthesis of novel pyrazolo $[3,4-b]$ quinolinyl acetamide analogs, their evaluation for antimicrobial and anticancer activities, validation by molecular modeling and CoMFA analysis. EurJ Med Chem 130:223-239

25. Caliendo G, Santagada V, Perissutti E, Severino B, Fiorino F, Warner TD, Wallace JL, Ifa DR, Antunes E, Cirino G, de Nucci G (2001) Synthesis of substituted benzamides as anti-inflammatory agents that inhibit preferentially cyclooxygenase 1 but do not cause gastric damage. Eur J Med Chem 36(6):517-530

26. Tian Y, Zhang T, Long L, Li Z, Wan S, Wang G, Yu Y, Hou J, Wu X, Zhang J (2018) Design, synthesis, biological evaluation and molecular modeling of novel 2-amino-4-(1-phenylethoxy) pyridine derivatives as potential ROS1 inhibitors. Eur J Med Chem 143:182-199

27. Guo J, Zhu M, Wu T, Hao C, Wang K, Yan Z, Huang W, Wang J, Zhao D, Cheng M (2017) Discovery of indolin-2-one derivatives as potent PAK4 inhibitors: structure-activity relationship analysis, biological evaluation and molecular docking study. Bioorg Med Chem 25(13):3500-3511

28. Avalakki AS, Jadhav SB, Bandawane DD, Bhalekar PA (2019) Synthesis and antidiabetic evaluation of some novel compounds. Indian J Chem 58:849-854

29. Giacobbo BC, Pissinate K, Rodrigues-Junior V, Villela AD, Grams ES, Abbadi BL, Subtil FT, Sperotto N, Trindade RV, Back DF, Campos MM (2017) New insights into the SAR and drug combination synergy of 2-(quinolin4-yloxy) acetamides against Mycobacterium tuberculosis. Eur J Med Chem 126:491-501

30. Foster JE, Nicholson JM, Butcher R, Stables JP, Edafiogho IO, Goodwin AM, Henson MC, Smith CA, Scott KR (1999) Synthesis, characterization and anticonvulsant activity of enaminones Part 6: Synthesis of substituted vinylic benzamides as potential anticonvulsants. Bioorg Med Chem 7(11):2415-2425

31. Carson JR, Coats SJ, Codd EE, Dax SL, Lee J, Martinez RP, Neilson LA, Pitis PM, Zhang SP (2004) N, N-Dialkyl-4-[(8-azabicyclo [32 1]-oct-3-ylidene) phenylmethyl] benzamides, potent, selective $\delta$ opioid agonists. Bioorg Med Chem Lett 14(9):2109-2112

32. Thakral S, Singh V (2019) 2,4-Dichloro-5-[(N-aryl/alkyl) sulfamoyl] benzoic acid derivatives: in vitro antidiabetic activity, molecular modeling and in silico ADMET screening. Med Chem 15(2):186-195

33. Thakral S, Singh V (2019) Synthesis, biological evaluation, QSAR, molecular docking and ADMET studies of N-aryl/N,N-dimethyl substituted sulphonamide derivatives. Anti-Infect Agents. https://doi.org/10.2174/22113 52517666190902130014

34. Singh R, Lather V, Pandita D, Judge V, Arumugam KN, Grewal AS (2017) Synthesis, docking and antidiabetic activity of some newer benzamide derivatives as potential glucokinase activators. Lett Drug Des Discov 14(5):540-553 
35. Charaya N, Pandita D, Grewal AS, Lather V (2018) Design, synthesis and biological evaluation of novel thiazol-2-yl benzamide derivatives as glucokinase activators. Comput Biol Chem 73:221-229

36. Grewal AS, Kharb R, Prasad DN, Dua JS, Lather V (2019) N-pyridin-2-yl benzamide analogues as allosteric activators of glucokinase: design, synthesis, in vitro, in silico and in vivo evaluation. Chem Biol Drug Des 93(3):364-372

37. Grewal AS, Sharma K, Singh S, Singh V, Pandita D, Lather V (2018) Design synthesis and antidiabetic activity of novel sulfamoyl benzamide derivatives as glucokinase activators. J Pharm Tech Res Manag 6(2):113-122

38. Adegboye AA, Khan KM, Salar U, Aboaba SA, Chigurupati S, Fatima I, Taha M, Wadood A, Mohammad Jl, Khan H, Perveen S (2018) 2-Aryl benzimidazoles: synthesis, in vitro a-amylase inhibitory activity, and molecular docking study. Eur J Med Chem 150:248-260

39. Taha M, Irshad M, Imran S, Chigurupati S, Selvaraj M, Rahim F, Ismail NH, Nawaz F, Khan KM (2017) Synthesis of piperazine sulfonamide analogs as diabetic-II inhibitors and their molecular docking study. Eur J Med Chem 141:530-537

40. Kumar CA, Veeresh B, Ramesha KC, Raj CA, Mahadevaiah KM, Prasad SB, Naveen S, Madaiah M, Rangappa KS (2017) Antidiabetic studies of 1-benzhydryl-piperazine sulfonamide and carboxamide derivatives. J Applicable Chem 6(2):232-240

41. Lad NP, Manohar Y, Mascarenhas M, Pandit YB, Kulkarni MR, Sharma R, Salkar K, Suthar A, Pandit SS (2017) Methylsulfonyl benzothiazoles (MSBT) derivatives: search for new potential antimicrobial and anticancer agents. Bioorg Med Chem Lett 27(5):1319-1324

42. Kim KY, Nguyen TH, Kurihara H, Kim SM (2010) a-Glucosidase inhibitory activity of bromophenol purified from the red alga Polyopes lancifolia. J Food Sci 75:145-150

43. Nguyen TH, Kim SM (2015) a-Glucosidase inhibitory activities of fatty acids purified from the internal organ of sea cucumber Stichopus japonicas. J Food Sci 80:841-847

44. Rani N, Sharma SK, Vasudeva N (2012) Assessment of antiobesity potential of Achyranthes aspera Linn. seed. Evid Based Complement Alternat Med. https://doi.org/10.1155/2012/715912

45. Biasini M, Bienert S, Waterhouse A, Arnold K, Studer G, Schmidt T, Kiefer F, Cassarino TG, Bertoni M, Bordoli L, Schwede T (2014) SWISS-MODEL: modeling protein tertiary and quaternary structure using evolutionary information. Nucleic Acids Res 42:W252-W258

46. Dauter Z, Dauter M, Brzozowski AM, Christensen S, Borchert TV, Beier L, Wilson KS, Davies GJ (1999) X-ray structure of novamyl, the five-domain "maltogenic" a-amylase from Bacillus stearothermophilus: maltose and acarbose complexes at $1.7 \AA$ resolution. Biochemistry 38(26):8385-8392

47. Trott O, Olson JA (2010) AutoDock Vina: improving the speed and accuracy of docking with a new scoring function, efficient optimization, and multithreading. J Comput Chem 31:455-461
48. Berendsen HJC, Grigera JR, Straatsma TP (1987) The missing term in effective pair potentials. J Phys Chem 91(24):6269-6271

49. Van Der Spoel D, Lindahl E, Hess B, Groenhof G, Mark AE, Berendsen HJ (2005) GROMACS: fast, flexible, and free. J Comput Chem 26(16):1701-1718

50. Jorgensen WL, Tirado-Rives J (1988) The OPLS [optimized potentials for liquid simulations] potential functions for proteins, energy minimizations for crystals of cyclic peptides and crambin. J Am Chem Soc 110(6):1657-1666

51. El-Gohary NS, Shaaban MI (2015) Antimicrobial and antiquorum-sensing studies. Part 3: synthesis and biological evaluation of new series of [1, 3, 4] thiadiazoles and fused [1, 3, 4] thiadiazoles. Arch Pharm 348:283-297

52. Lipinski CA, Lombardo F, Dominy BW, Feeney PJ (2001) Experimental and computational approaches to estimate solubility and permeability in drug discovery and development settings. Adv Drug Deliv Rev 46:3-26

53. Cardoso MF, Rodrigues PC, Oliveira MEI, Gama IL, da Silva IM, Santos IO, Rocha DR, Pinho RT, Ferreira VF, de Souza MCB, da Silva FDC (2014) Synthesis and evaluation of the cytotoxic activity of 1,2-furanonaphthoquinones tethered to 1, 2, 3-1 $\mathrm{H}$-triazoles in myeloid and lymphoid leukemia cell lines. Eur J Med Chem 84:708-717

54. Veber DF, Johnson SR, Cheng HY, Smith BR, Ward KW, Kopple KD (2002) Molecular properties that influence the oral bioavailability of drug candidates. J Med Chem 45:2615-2623

55. Murugavel S, Kannan D, Bakthadoss M (2016) Experimental and computational approaches of a novel methyl (2E)-2-\{[N-(2-formylphenyl) (4-methylbenzene) sulfonamido] methyl\}-3-(4-chlorophenyl) prop-2enoate: a potential antimicrobial agent and an inhibition of penicillinbinding protein. J Mol Struct 1115:33-54

56. Balam SK, Krishnammagari SK, Harinath JS, Sthanikam SP, Chereddy SS, Pasupuleti VR, Yellapu NK, Peddiahgari VGR, Cirandur SR (2015) Synthesis

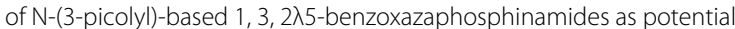
$11 \beta$-HSD1 enzyme inhibitors. Med Chem Res 24:1119-1135

57. de Oliveira KN, Souza MM, Sathler PC, Magalhaes UO, Rodrigues CR, Castro HC, Palm PR, Sarda M, Perotto PE, Cezar S, de Brito MA (2012) Sulphonamide and sulphonyl-hydrazone cyclic imide derivatives: antinociceptive activity, molecular modeling and in silico ADMET screening. Arch Pharm Res 35:1713-1722

\section{Publisher's Note}

Springer Nature remains neutral with regard to jurisdictional claims in published maps and institutional affiliations.
Ready to submit your research? Choose BMC and benefit from:

- fast, convenient online submission

- thorough peer review by experienced researchers in your field

- rapid publication on acceptance

- support for research data, including large and complex data types

- gold Open Access which fosters wider collaboration and increased citations

- maximum visibility for your research: over $100 \mathrm{M}$ website views per year

At BMC, research is always in progress.

Learn more biomedcentral.com/submissions 